\title{
PUBLIC LAW BY PRIVATE BARGAIN: TITLE VII CONSENT DECREES AND THE FAIRNESS OF NEGOTIATED INSTITUTIONAL REFORM
}

\author{
MAIMON SCHWARZSCHILD*
}

\begin{abstract}
Large-scale Title VII remedies are typical of "public law" litigation, which differs in kind from the conventional compensatory lawsuit. Title VII remedies are commonly adopted by way of consent decrees. By approving these consent decrees, federal courts take responsibility for extensive institutional reforms while acting independently of the adversary process. Courts have frequently approved consent decrees without fair hearings for those whose interests are at stake. Professor Schwarzschild suggests a systematic procedure for approving Title VII consent decrees. This procedure would not discourage settlements, but would ensure that courts act on the basis of fair hearings, consistently with the quasi-legislative character of public law remedies.
\end{abstract}

The federal courts have increasingly become the forum for litigation over the policies of large public and private institutions. These lawsuits-sometimes called "public law"l or "structural" cases"-involve essentially political questions, although the cases remain adjudicative in form. These cases give the courts broad discretion to decide matters of public policy and they often affect large numbers of people, imcluding many who are not parties to the lawsuits. Lawsuits of this kind are fraught with distimctive ambiguities that stem from the quasi-

* Associate Professor of Law, University of San Diego. B.A. 1973, J.D. 1976, Columbia University. Trial Attomey, 1976-1981, Civil Rights Division, U.S. Department of Justice.

This article was made possible by the insistence of Barry A. Miller, by research grants from the University of San Diego School of Law, and by the help and advice of David L. Rose, Lorna Grenadier, Lawrence Alexander, Sheldon Krantz, Stanley Paulson, Jessica Harrison, and my student assistants Mark Barbolak and Duncan Edwards. Any mistakes are nuy responsibility, although it seems to me that some culpability should be shared by these friends and colleagues who read the article and who are entitled, after all, to some of the credit.

1. See Chayes, The Supreme Court, 1981 Term-Foreword: Public Law Litigation and the Burger Court, 96 HARv. L. REv. 4, 6 (1982) [hereinafter cited as Chayes, Public Law Litigation and the Burger Courl]; Chayes, The Role of the Judge in Public Law Litigation, 89 HARv. L. Rev. 1281, 1284 (1976).

2. See Fiss, The Supreme Court, 1978 Term-Foreword: The Forms of Justice, 93 HARv. L. Rev. 1, 2 (1979) (describing the structural suit as one that attenpts to restructure the state bureaucracy by injunction) [hereinafter cited as Fiss, Forms of Justice]; see also O. Fiss, INJUNCTIONs 415-81 (1972). 
legislative character of the decisions at stake. ${ }^{3}$

There is a reinarkable tendency for this sort of case to culminate in a consent decree-a broad injunction negotiated by the parties and ratified as a court order by the signature of a federal judge. Consent decrees first became promment in antitrust cases, ${ }^{4}$ and are now common in every variety of lawsuit over public policy, including environmental cases, ${ }^{5}$ litigation over the rights of the institutionalized, ${ }^{6}$ school and lousing desegregation suits, ${ }^{7}$ and equal einployinent litigation. ${ }^{8}$

By approving consent decrees in public law cases, courts put their authority behind extensive reforms in the operations of inajor American institutions. What is more, consent decrees allow the courts to do this independently of the traditional adversary process. If public law litigation gives the courts an anomalously "legislative" power over public policy, consent decrees compound the anoinaly by invoking this power outside the context of adversary litigation.

This article is about consent decrees under one "public law" statute: Title VII of the Civil Rights Act of 1964.9 Title VII prohibits einployment discrimination on the basis of race, sex, color, rehigion, or national origin, ${ }^{10}$ and it does so in rather general terms. It is a paradigmatic piece of "public" legislation, not least in the way that it relegates to the federal courts the task of givmg specific content to the law. The Title VII remedies actually adopted by the courts often prescribe extensive "affirmative action," including racial quotas for hirmg and promotions. In most cases, moreover, courts adopt these controversial

3. Cf. Friendly, The Courts and Social Policy, 33 U. Mram1 L. Rev. 21, 40 (1978) (elaborate affirmative decrees rendered by courts to resolve social issues are inherently ambiguous and courts should recognize that such decrees have the qualities of social legislation).

4. See, e.g., Swift \& Co. v. United States, 276 U.S. 311, 319-20 (1927) (affirming consent decree where parties in the antitrust case consented to it without any findings of fact or admission of wrongdoing). Consent decrees are still very common in antitrust cases. See North Am. Tel. Ass'n v. United States, 460 U.S. 1001 (1983) (mein.) (approving an antitrust consent decree that is radically transforming the telephone and telecommunications industry), affg United States v. American Tel. \& Tel. Co., 552 F. Supp. 131 (D.D.C. 1982).

5. See, e.g., Citizens For a Better Env't v. Gorsuch, 718 F.2d 1117, 1129 (D.C. Cir. 1983) (affirming an envirounental consent decree); Natural Resources Defense Council v. Costle, 561 F.2d 904, 906-07 (D.C. Cir. 1977).

6. See, e.g., New York State Ass'n for Retarded Children, Inc. v. Carey, 393 F. Supp. 715, 719 (E.D.N.Y. 1975) (mein.) (consent decree guaranteeing inmates of the state facility a stipulated level of care).

7. See, e.g., Metropohtan Housing Dev. v. Village of Arlington Heights, 616 F.2d 1006, 1015 (7th Cir. 1980) (affirming approval of cousent decree in action alleging racially discriminatory zoning); United States v. Board of Educ., 88 F.R.D. 679, 681 (N.D. Ill. 1981) (Inein.) (consent decree entered in a suit to require the city to desegregate schools on a systennwide basis).

8. See infra notes $40-42$ and accompanying text.

9. 42 U.S.C. $\$ 2000 \mathrm{e}$ (1982).

10. 42 U.S.C. $§ 2000 \mathrm{e}-2$ (1982). 
remedies by way of consent decrees. ${ }^{11}$

The question underlying this article is whether such remedies can be adopted by unlitigated court order in a way that is fair to all concerned. "Affirmative action" remedies can have lasting effects on the working hives of many people-minority and white, inale and feinalebut many of the people directly affected are not parties to the lawsuits that bring forth these remedies. Courts have become increasingly attentive to the rights of class ineinbers in civil rights class actions. ${ }^{12}$ In a Title VII suit brought by a government civil rights agency, however, there is no plaintiff class, so class action safeguards do not protect the putative beneficiaries of the lawsuit. This is particularly significant now, because the Reagan administration refuses to be party to certain "affirmative action" reinedies that might be sought by private plaintiffs. As for white employees and job applicants, their interests often go entirely unrepresented in government suits and class actions alike.

The Umited States Supreme Court recently declined to review the case of a group of white job applicants whose "reverse discrimination" suit against a public employer had been dismissed without trial by the lower federal courts. ${ }^{13}$ The lower courts had dismissed the suit because of the existence of a consent decree between the employer and a class of minority Title VII plaintiffs. ${ }^{14}$ The denial of certiorari drew a dissent by Justices Rehnquist and Brennan-an odd couple-who observed that a consent decree is not an adjudication on the merits and who questioned the fairness of treating such a decree as precluding litigation by nonparties to the agreement. ${ }^{15}$ Justices Rehnquist and Brennan identify a very real problein, but this article will suggest that their imphed solution, namely litigation of the inerits of the case, undervalues the practical benefits of consensual settlements in public law cases.

11. See infra notes $36-42$ and accompanying text.

12. See infra notes $133-43$ and accompanying text. There is a growing body of literature on the rights of class members in civil rights class actions. See, e.g., Anderson, The Approval and Interpretation of Consent Decrees in Civil Rights Class Action Litigation, 1983 U. ILL. L. REv. 579, 586 (noting that judges must ensure that agreements reached by the parties adequately protect the rights of absentee class members); Rutherglen, Notice, Scope, and Preclusion in Title VII Class Actions, 69 VA. L. REv. 11, 83 (1983) (concluding that the preclusive effect of a Title VII class action should be established at the earliest opportunity in litigation through class certification, definition of its scope based on the claims of the named plaintiffs, and notice to class members with an accompanying right to "opt out").

13. Ashley v. City of Jackson, 104 S. Ct. 255 (1983).

14. Thaggard v. City of Jackson, 687 F.2d 66, 67-68 (1982) (holding plaintiffs' "reverse discrimmation" complaints to be impermissible collateral attacks on consent decrees), cert. denied, 104 S. Ct. 255 (1983).

15. Ashley v. City of Jackson, 104 S. Ct. 255, 256-59 (1983) (Rehnquist, J., dissenting). 
The article is divided into four parts. Part I explains why Title VII is a very good exainple of "public law" and points out how commonly Title VII cases are resolved by consent decrees. ${ }^{16}$ Part II describes a typical Title VII settleinent and assesses why consent decrees are cominon in structural Title VII cases. ${ }^{17}$ Part III considers the constitutional and jurisprudential anoinalies of public law consent decrees, and suggests why these very anoinalies make consent decrees compatible with public law adjudication while simultaneously creating special problcms of fairness. ${ }^{18}$ The final section focuses on low erratically the courts have given a hearing to the "third parties" who are directly affected by these decrees, and recommends a systematic procedure for approving or refusing to approve consent decrees. ${ }^{19}$ The suggested procedure would not discourage settlements, but would ensure that courts act only after providing fair hearings for the various interests at stake, consistently with the quasi-legislative character of public law remedies.

\section{Title VII: A Quintessential Example of Public LaW}

Title VII litigation is an excellent exainple of "public law" or "structural" litigation. ${ }^{20}$ Title VII itself is "public" in the nost obvious sense that equal employnent opportunity is promment on the national agenda. In the years since Title VII was adopted it has perhaps become a commonplace that racial mimorities should not be denied jobs "because of the color of their skin," but "affirinative action" continues to be enorinously provocative - one of the "legal" issues that ordmary Americans are most likely to be aware of and to have opinions about. By prohibiting discrimination in general teruns, ${ }^{21}$ Congress implicitly invited the courts to nake the basic policy decisions in this politi-

16. See infra notes $20-42$ and accompanying text.

17. See infra notes $43-78$ and accompanying text.

18. See infra notes 79-110 and accompanying text.

19. See infra notes 111-218 and accompanying text.

20. See O. Fiss, The Civil Rights InJunction 7 (1978); Fiss, Forms of Justice, supra note 2, at 2; see also Chayes, The Role of the Judge in Public Law Litigation, supra note 1, at 1284.

21. Title VII provides in pertiment part:

(a) It shall be an unlawful employment practice for an employer-

(1) to fail or refuse to hire or to discharge any individual, or otherwise to discriminate against any individual with respect to his compensation, terms, conditions, or privileges of employment, because of such individual's race, color, retigion, sex, or national origin; or

(2) to limit, segregate, or classify his employees or applicants for employment in any way which would deprive or tend to deprive any individual of employment opportunities or otherwise adversely affect his status as an employee, because of such imdividual's race, color, religion, sex, or national origin.

42 U.S.C. $\$ 2000 \mathrm{e}-2$ (a) (1982). Cf. 42 U.S.C. $\$ 2000 \mathrm{e}-2$ (h) (1982) (apparently immunizing from liability any bona fide semiority or merit selection system). See also 42 U.S.C. $\$ 2000$ e (1982) ("Definitions" which include no definition of "discrimination"). 
cally charged area. The statute does not define discrimination and does not specify how it should be proved. Thus, it is the Supreme Court, not Congress, that established that tests, educational requirements, or other job qualifications "neutral on their face and even neutral in terms of intent" may violate Title VII if they have a disproportionate racial impact. ${ }^{22}$ To a very considerable degree, the courts have defined the "right" afforded by Title VII: not only the right to be free of deliberately bigoted employment practices but also the right to be free of many job requirements that disproportionately hurt a particular race, sex, or ethnic group.

Like the "right," the "remedy" is largely judicially defined. The Supreme Court, while endorsmg Title VII as a charter for broad remedial decrees, ${ }^{23}$ has generally left it to the lower courts to decide what relief to order. Even the remedies explicitly approved by the Supreme Court can have a significant impact on an employer's workplace, as, for example, when the Court endorsed the award of "retroactive seniority" to victims of hiring discrimination. ${ }^{24}$ In inany industries, seniority affects an employee's working conditions and his likelihood of being laid off; an award of retroactive semority to one group of employees whoin the employer discriminated against in the past will affect the status of other-for instance, white-employees in the future. ${ }^{25}$

22. See Griggs v. Dnke Power Co., 401 U.S. 424,430 (1971). A test or job qualification has "adverse impact" if it scrcens out proportionately more minority applicants than whites. Under the principles established by the courts, an employer who is sued under Title VII can justify a job requirement that has adverse impact only if the employer convinces the courts that the requirement is a "business necessity." See Albeinarle Paper Co. v. Moody, 422 U.S. 405, 434 (1975). This, in turn, usually entails "validating" the requirement by demonstrating its correlation with success on the job. The federal agencies that enforce Title VII have propounded very technical and deınandimg guidelines for "validating" job requirements. See Uniforin Guidelines on Employee Selection Procedures, 29 C.F.R. $\$ \S 1607.1$-.18 (1984) [heremafter cited as Uniform Guidelines]. These guidelines are generally given "great deference" by the courts. See Griggs, 401 U.S. at 434. Cf. Bartholet, Application of Title VII to Jobs in High Places, 95 HARv. L. REv. 945, 956 n.29 (1982) (noting that it is difficult to satisfy the Guidelines and to sustain the burdens of proof laid down for einployers in Griggs and related cases).

Courts have been less stringent about requiring validated job qualifications for highly skilled jobs. See New York City Transit Auth. v. Beazer, 440 U.S. 568, 594 (1979); Spurlock v. United Airlines, Inc., 475 F.2d 216, 219 (10th Cir. 1972). See generally, Maltz Title VII and Upper Level Employment-A Response to Professor Bartholet, 77 Nw. U.L. REv. 776 (1983).

23. See, e.g., International Bhd. of Teamsters v. United States, 431 U.S. 324, 364 (I977) (holding that Title VII imtended to vest broad equitable powers in the courts); Franks v. Bowman Transp. Co., 424 U.S. 747, 763 (1976); Albeinarle Paper Co. v. Moody, 422 U.S. 405, 418 (1975).

24. See International Bhd. of Teamsters v. United States, 431 U.S. 324, 347-48 (1977); Franks v. Bowman Transp. Co., 424 U.S. 747, 762-70 (1976).

25. See Zipes v. Trans World Airlines, Inc., 455 U.S. 385, $398-99$ (1982) (upholding such semiority relief despite the effects on white employces). But see infra note 56. 
Federal district courts and courts of appeals, for their part, issue sweeping remedial injunctions in Title VII cases that fundamentally reshape the personnel policies of employers found liable for discrimination. Sucl remedies are designed not merely to correct the employer's specific misdeeds, but to create a new climate for einployment decisions in the future. Einployers have been ordered to change their recruitment policies, ${ }^{26}$ to develop new tests for selecting job applicants, ${ }^{27}$ to desegregate job assignments, ${ }^{28}$ to institute training programs for minority employees, ${ }^{29}$ and to institute hiring and promotion quotas. $^{30}$

Title VII reinedies, as such, are only loosely related to the violations they are intended to cure. ${ }^{31}$ This is because the specifics of a broad prospective remedy do not follow inexorably from the fact that

26. See, e.g., United States v. Hazelwood School Dist., 534 F.2d 805, 812-13 (8th Cir. 1976), rev'd on other grounds, 433 U.S. 299 (1977).

27. See, e.g., Guardians Ass'n of N.Y. City Police Dep't v. Civil Service Comm'n, 630 F.2d 79, 109-10 (2d Cir. 1980), cert. denied, 452 U.S. 940 (1981).

28. See, e.g., United States v. Bethlehem Steel Corp., 446 F.2d 652, 666 (2d Cir. 1971); Bowe v. Colgate-Palmolive Co., 416 F.2d 711, 715-18 (7th Cir. 1969).

29. See, e.g., Ostapowicz v. Johnson Bronze Co. 541 F.2d 394, 401 (3d Cir. 1976), cert. denied, 429 U.S. 1041 (1977); see also EEOC v. International Union of Elevator Constructors Local 5, 398 F. Supp. 1237, 1264-65 (E.D. Pa. 1975), affd on other grounds, 538 F.2d 1012 (3d Cir. 1976).

30. See, e.g., Association Against Discrimination v. City of Bridgeport, 647 F.2d 256, 280-84 (2d Cir. 1981) (requiring that 102 minority candidates be offered firefighter positions before anyone else hired), cert. denied, 455 U.S. 988 (1982); United States v. City of Buffalo, 633 F.2d 643, 646 (2d Cir. 1980); Firefighters Inst. for Racial Equality v. City of St. Louis, 616 F.2d 350, 364 (8th Cir. 1980), cert. denied, 452 U.S. 938 (1981); Boston Chapter NAACP v. Beecher, 504 F.2d 1017, 1026 (1st Cir. 1974), cert. denied, 421 U.S. 910 (1975); Rios v. Enterprises Assoc. Steam Fitters Local 638, 501 F.2d 622, 629 (2d Cir. 1974); Carter v. Gallagher, 452 F.2d 315, 324 (8th Cir.), cert. denied, 406 U.S. 950 (1972); Contractor Ass'n of E. Pa. v. Secretary of Labor, 442 F.2d 159, 170 (3d Cir.), cert. denied, 404 U.S. 854 (1971); Louisville Black Police Officers Org., Inc. v. City of Louisville, 511 F. Supp. 825, 839 (W.D. Ky. 1979), affd, 700 F.2d 268 (6th Cir. 1983); see also Edwards \& Zaretsky, Preferential Remedies for Employment Discrimination, 74 Mich. L. REv. 1, 27-28 (1975) (pointing out that inany courts treat quotas as an extreme remedy suitable only for egregious cases of discrimination).

31. Of course, when an employer violates Title Vll by denying someone a job on account of race or sex, it is entirely consistent with the most traditional model of hitigation to order the employer to offer the person the job, with retroactive semority and back pay. Such remedies are closely linked to the violation, they redress an individual gricvance, they do not require any particular creativity or discretion, and they have limited impact on third parties. "Affirmative action" measures such as quotas, on the other hand, are for the benefit of any member of a designated mimority group, without regard to whether a particular beneficiary has been discriminated against by the employer in the past. In practice, "race-conscious" relief generally means some preference for inembers of the minority group. See J. Livingstone, FaIR GAME? INEQUALITY AND AFFIRMATIVE ACTION 11 (1979) ("Affirmative action means preference on the basis of race or it [means] nothing."). The preference is a "remedy" only in a loose or metaphorical sense, because the individuals receiving "compensation" are inost often not victims of past wrongdoing by the employer. See Brest, The Supreme Court 1975 Term-Foreword: In Defense of the Antidiscrimina. tion Principle, 90 Harv. L. Rev. 1, 41-42 (1976). 
the employer has been found guilty of discrimination. A different quota - higher or lower - would not be unthinkable, nor would a different examination or scoring procedure for the examination, an alternate training program, or a different seniority scheme. ${ }^{32}$ Choosing such a remedy is a matter of discretion: it "necessarily involves a degree of approximation and imprecision" 33 because no particular policy choice for the future follows automatically from the employer's past violation of Title VII.

All this makes Title VII hitigation a formidable example of "public law." The outcome of a Title VII case may be to restructure an employer's entire process of selecting, hiring, traming, assigning, promot$\mathrm{mg}$, and firing staff. Such a remedy affects not only the parties-the plaintiffs and the employer-but also the incumbent employees, future applicants, and the economic and noral interests of society as a whole. When fashioning a decree, the court should properly take account of all these interests, while vindicating the values implicit in Title VII. Because of the variety of interests at stake and the fact that there is no automatic "right answer" about the decree's contents, a court must exercise discretion when it adjudicates a Title VII case. With an ambiguity characteristic of "public law," there is a convergence of discretionary pohicymaking and old-fashioned adjudication in any large-scale Title VII remedy. ${ }^{34}$

Title VII is also "public" in another sense, namely that it has had a palpable impact on American behavior. "Affirmative action" has become entrenched in the manageinent of inost American institutions, as affirmative action officers, utilization studies, goals and timetables, and, above all, the widespread subjective awareness of "affirmative action" as a legal or moral obligation have followed froin Title VII. ${ }^{35}$

One widespread form of "comphance" with Title VII has been for employers to sign consent decrees when sued or threatened with suit, rather than attempting to prove their innocence or trying to persuade a judge to impose a mild remedy. Thus, when the Justice Departinent

32. "There are nine and sixty ways/of constructing tribal lays/and every single one of them is right." R. KIPLING, In the Neolithic Age, in BARRACK Room Ballads, 342 (1940) (stanza 5).

33. Interuational Bhd. of Teamsters v. United States, 431 U.S. 324, 372 (1977).

34. See 2 K. Davis, Administrative Law Treatise $\$ 7: 2$ (2d ed. 1978) (on the ambiguous distinction in adininistrative law between a quasi-adjudicatory "order" and the adininistrative "rule-1naking" that resembles legislation); see also id. at $\$ 2: 13$ (on the relationship of lawmaking to the exercise of discretionary power, especially discretionary power exercised by bodies other than the elected legislature).

35. Of course, it is not just litigants, people or institutions that have sued or been sued, who are affected. The law shapes the behavior of many who have not been involved in Title V11 hitigation as well as those comparatively few who have been. The effectiveness of any law depends on compliance by persons who are not directly coerced by the court. 
and the Equal Employment Opportunity Commission (EEOC) sued the American Telephone and Telegraph Company ${ }^{36}$-a conglomerate whose subsidiary companies at the time constituted the largest private employer in the country ${ }^{37}$ - the case was settled with an elaborate consent decree. ${ }^{38}$ Consent decrees also resulted from the government's Title VII suit against the nine inajor steel companies that, according to the coinpanies involved, constituted seventy-three percent of the country's basic steel industry and employed a total of more than 300,000 people. ${ }^{39}$ The federal civil service is extensively revising its hiring policies under a Title VII consent decree which, in part, calls for the abolition of the written test-the PACE exam-that had been used to screen applicants for jobs in the federal bureaucracy. ${ }^{40}$ Between 1972 and 1983, the Justice Department sued and obtamed relief under Title VII against 106 state and local government employers; ${ }^{41}$ of these cases, ninety-three-some eighty-eight percent-were settled by consent decree. ${ }^{42}$ It would be fair to say that far inore employees and job applicants are directly affected by the provisions of consent decrees than by litigated judgments im Title VII cases.

\section{Title VII Consent Decrees}

\section{A. The Consent Decree Defined and Illustrated.}

A consent decree is a settlement agreement among the parties to a lawsuit, signed by the court and entered as a judgment in the case. It is a kind of legal hermaphrodite, with characteristics both of a contract and of a court order. It is contractual in the obvious sense that it is drafted and agreed upon by the parties: it is their bargam, it represents

36. EEOC v. American Tel. \& Tel. Co., 556 F.2d 167 (3d Cir. 1977), cert. denied, 438 U.S. 915 (1978).

37. See EEOC v. American Tel. \& Tel. Co., 365 F. Supp. 1105, 1108 n.1 (E.D. Pa. 1973), modified 506 F.2d 735 (3d Cir. 1974).

38. EEOC v. American Tel. \& Tel. Co., 556 F.2d 167, 173-74 (3d Cir. 1977), cert. denied, 438 U.S. 915 (1978).

39. United States v. Allegheny-Ludlum Indus., 517 F.2d 826, 834 (5th Cir. 1975), cert. denied, 425 U.S. 944 (1976).

40. Luevano v. Campbell, 93 F.R.D. 68,73 (D.D.C. 1981). More than 700,000 persons took the PACE exam between 1976 and 1980 . Id. at 75 .

41. Under the 1972 amendmeuts to Title VII, the EEOC has jurisdiction to sue employers in the private sector and the Justice Department is essentially restricted to enforcing Title VII against state and local government agencies. Equal Employinent Opportunity Act of 1972, Pub. L. No. 92-261, \$4, 86 Stat. I03, $104-07$ (1972) (codified as ainended at 42 U.S.C. $\$ 2000 \mathrm{e}-5$ (1982)).

42. Files mamtained at the United States Department of Justice corroborate this figure. Thirteen of the ninety-three consent decrees were negotiated after there had been a trial on the merits. Another thirteen cases were tried and resulted in a court order without a consent decree. 
the terms on which they are prepared to settle. ${ }^{43}$ But a consent decree is not just a private contract. Unlike a contract, or a private out-ofcourt settlement, a consent decree can be enforced by citation for contempt of court; it has the authority of a judicial decree. ${ }^{44}$ Moreover, like any mjunction, a consent decree can also be modified by the court, even over the objections of a party, in order "to effectuate the basic purpose of the decree." 45

Consent decrees in Title VII cases are as varied as the cases theinselves, but at least in "pattern-or-practice" suits brought by the federal government, ${ }^{46}$ and in comparable class actions by private plaintiffs, ${ }^{47}$ a consent decree typically includes some or all of the following provisions:

(1) A recital that the complaint has been filed and that the parties agree to the decree although the defendant admits no hability; 48

(2) An injunction against unlawful discrimination in the future on the basis of race or sex against any employee or applicant for employment; 49

(3) A stipulation of what the employer must do to recruit minority applicants. The decree might specify, for instance, where the employer must advertise, or what the ads should say, or that there inust be a fullor part-time minority recruiter, or how mucl money must be spent on recruitment; 50

(4) A provision forbidding the use of any written test or otler job qualification that disproportionately screens out minority applicants for employment or for proinotion, unless the test has been validated under

43. Courts sometimes hold, therefore, that consent decrees must be construed by the same rules as are contracts. See, e.g., United States v. ITT Contmental Baking Co., 420 U.S. 223, 238 (1975), quoted in Brown v. Neeb, 644 F.2d 551, 557 (6th Cir. 1981).

44. See, e.g., EEOC v. Local Union No. 38, 28 Fair Empl. Prac. Cas. (BNA) 1567, 1575 (N.D. Cal. 1981) (contempt citation).

45. A contested modification requires a hearing and findings of fact. See Umited States v. Atlantic Ref. Co., 360 U.S. 19, 23 (1959). The object of the hearing, however, is not to litigate the merits of the original lawsuit, but rather to consider whether modification is justified im hight of the pohcy underlying the consent decree and the events that have occurred since the decree was approved. See Brown v. Neeb, 644 F.2d 551, 560 (6th Cir. 1981).

46. See 42 U.S.C. $\$ 2000$ e-6 (1982) (providing the statutory basis for such suits).

47. See, e.g., Blake v. City of Los Angeles, 595 F.2d 1367, 1372 (9th Cir. 1979) (class action brought by private plamtiffs), cert. denied, 446 U.S. 926 (1980).

48. See, e.g., EEOC v. American Tel. \& Tel. Co., 556 F.2d 167, 176 (3d Cir. 1977), cert. denied, 438 U.S. 915 (1978); see also United States v. Swift \& Co., 286 U.S. 106, 111 (1931).

49. See, e.g., United States v. City of Chicago, 549 F.2d 415, 439 (7th Cir.), cert. denied, 434 U.S. 875 (1977); Lamphere v. Brown Univ., 491 F. Supp. 232, 238 (D.R.I. 1980), affd, 685 F.2d 743 (1st Cir. 1982).

50. See, e.g., United States v. Sheriff of Lancaster Country, 561 F. Supp. 1005, 1012 (E.D. Va. 1983); Guardians Ass'n of N.Y. City v. Civil Serv. Comm'n, 527 F. Supp. 751, 755 (S.D.N.Y. 1981). 
the Uniform Guidelines on Employee Selection Procedures; ${ }^{51}$

(5) A hiring "goal" or quota. This is often couched in the form of an "ultimate goal" that the employer's staff should reflect the racial or sexual makeup of the labor force upon which the employer draws, ${ }^{52}$ and an "imterim" quota-usually higher than the ultimate goal-imposed in order to achieve the ultimate goal within a foreseeable period of years. Such a quota typically stipulates that some proportion of all vacancies for a period of years must be filled by minorities; ${ }^{53}$

51. Uniform Guidelines, supra note 22 , at $\$ 1607.1$. Because some minority groups-blacks especially-score lower, on average, than do whites on most written tests, and because "validation" is difficult and expensive, such a provision discourages the use of tests, or at least discourages hiring or promotion im "rank order" on the basis of test scores. When test scores are used in "rank order," the first job goes to the apphicant with the highest score, the second job to the second highest scorer, and so forth.

A test's "adverse impact" on nuinorities can sometimes be reduced or elimmatcd by using the test on a "pass-fail" basis, especially if the minimum passing score is not set too high. This approach permits the employer to screen out the lowest-scoring applicants witlout necessarily screening out all the minority apphicants. The einployer must then decide on the basis of something other than the test scores whom to hire or promote first. The logic of this approach is that an apphicant who gets a 91 on the test will not necessarily be a better worker than one who gets a 90 , while an applicant who fails the test entirely might really be a poor einployment risk. See United States v. Georgia Power Co., 474 F.2d 906, 917 (5th Cir. 1973) ("no relationship was demonstrated between successful job performance and the abihty to achieve the Company-established cut-off score" on the test); Alexander v. Bahou, 86 F.R.D. 194, 197-98 (N.D.N.Y. 1980) (racial hiring goals shall be accomphished by hiring candidates who have passed an "appropriate" civil service exam).

52. See, e.g., Jones v. Milwaukee County, 85 F.R.D. 715, 718 (E.D. Wis. 1980); Officers for Justice v. Civil Serv. Comm'n, 473 F. Supp. 801,813 (N.D. Cal. 1979) (goal of hiring scheme under consent decree is to create a work force that "reflects the racial, ethnic and sexual composition of the relevant labor force"), cert. denied, $103 \mathrm{~S}$. Ct. 1219 (1982). For a relatively unskilled job this labor force might be the local labor force as a whole; for a more specialized job it might be the local, regional, or national class of persons with the minimum necessary skills or education.

53. Under the Reagan administration, which is on record as opposing quotas, the United States Department of Justice in its Title VII enforcement actions no longer enters into consent decrees requiring quota hiring or promotion. See UnITEd STATES DeParTMENT of JustiCE, LeGAL ACTIVITIES: 1984-1985, 19 ("The Employment Litigation Section . . . does not use preferential selection requirements that confer an undeserved benefit on nonvictims of discrinnination" [i.e., quotas] in its Title VII hitigation.). It does, however, sign decrees providing that the einployer should recruit enough qualified mimority apphicants so that a stated percentage of all applicants will be minorities. The decrees state the "expectation" that nondiscriminatory hiring should result in approximately the same percentage of mimorities being hired as apply. See, e.g., United Statcs v. New Hampshire, No. 81-457-D (D.N.H. Sept. 17, 1981); United States v. Vermont, No. 81-380 (D. Vt. Dec. 14, 1981). This is somewhat "softer" than an explicit quota, but if an employcr hired a significantly smaller percentage of minorities than apphed, then only a "valid" sclection process would justify the "adverse impact." See Uniform Guidelines, supra note 22, at $\$ 1607.3$ (a).

As a practical matter, the "recruitment goals" generally reflect the percentage of qualified mimorities in the work force upon which the defendant draws; such a "recruitment goal" is apt to be somewhat lower than the "interim goals and timetables" which were designed to accelerate the process of integration. Again, as a practical matter, it may be easier under the new, more gentlyworded decrees for a defendant to convince a court that it is complying in good faith even if it falls somewhat short of recruiting and hiring in the stipulated percentages. 
(6) A promotion "goal" or quota. This is similar to a hiring quota except that a promotion goal reserves a stipulated proportion of promotions to minorities or women; 54

(7) Provisions requiring that training programs be open to ininorities and women, and that minorities and women may not be disfavored in assignments, discipline, and fringe benefits; 55

(8) Seniority rehef. The employer may agree to grant seniority to victims of discrimination, retroactive to the time they should have been hired; 56

(9) Back pay. The employer may agree to pay a stipulated sum in back pay to victims of job discrimination, or to set aside a sum of money to be distributed under court supervision according to a forinula to be agreed upon later. ${ }^{57}$ In a class action brought by private plaintiffs, as opposed to a suit by a federal civil rights agency, the decree may also include plaintiffs' attorney fees; ${ }^{58}$

(10) Recordkeeping and reporting requirements; 59

(11) Appointment of a nonitor. A few decrees, but by no means a majority, have provided for the appointment of a monitor or officer to oversee administration of the decree and to try to resolve disputes that might arise; ${ }^{60}$ and

(12) A stipulation that the court retain jurisdiction of the case and that the parties may file motions for interpretation ${ }^{61}$ or modification of

54. See, e.g., Vulcan Soc'y v. City of New York, 96 F.R.D. 626, 628 (S.D.N.Y. 1983) (settlement provides that a sufficient number of black firefighters must be promoted so as to achieve a work-force ratio of $3.7 \%$ ).

55. See, e.g., EEOC v. Safeway Stores, Inc., 634 F.2d 1273, 1277 (10th Cir. 1980), cert. denied, 451 U.S. 986 (1981); Moore v. City of San Jose, 615 F.2d 1265, 1269 (9th Cir. 1980).

56. See, e.g., Zipes v. Trans World Airlines, Inc., 455 U.S. 385, 390 (1982) (stewardesses who had been dismissed for pregnancy in violation of Title VII reinstated with seniority retroactive to the date they were originally hired); see also United Airlines v. Evans, 431 U.S. 553, 559 (1977). Cf. International Bhd. of Teamsters v. United States, 431 U.S. 324, 352-53 (1977) (bona fide seniority system is not itself illegal under Title VII even if it perpetuates the advantages of whites hired discriminatorily before Title VII went into effect); accord, Firefighters Local Union No. 1784 v. Stotts, 104 S. Ct. 2576, 2587-89 (1984).

57. See, e.g., Officers For Justice v. Civil Serv. Comm'n, 688 F.2d 615, 627-30 (9th Cir. 1982), cert. denied, 459 U.S. 1217 (1983).

58. See, e.g., Sargeant v. Sharp, 579 F.2d 645, 647 (1st Cir. 1978) (award of attorney fees for plaintiffs' lawyers not necessarily precluded when the case concludes with consent decree); see also 42 U.S.C. \& 2000e-5(k) (1982) (Title VII provision authorizing attorney fees for the "prevailing party").

59. See, e.g., Sanders v. Shell Oil Co., 678 F.2d 614, 617-18 n.3 (5th Cir. 1982); United States v. Sheriff of Lancaster County, 561 F. Supp. 1005, 1014 (E.D. Va. 1983).

60. See, e.g., Officers For Justice v. Civil Serv. Comm'n, 688 F.2d 615, 636 (9th Cir. 1982), cert. denied, 459 U.S. 1217 (1983).

61. On the interpretation of consent decrees, see Anderson, supra note 12, at 615-32. 
the decree. ${ }^{62}$ A decree usually remains in effeet for a stipulated number of years-commonly five or ten-but often provides that any party can move for earlier dissolution or extension of its life, depending on whetlier the objectives of the decree have been inet. ${ }^{63}$

\section{B. Title VII Consent Decrees-Their Popularity Explained.}

Consent decrees are common in Title VII cases, ${ }^{64}$ im part because settlement is always an attractive alternative to litigation, in part because consent decrees are virtually symbiotic witlı public law, and in part because of some specific characteristics of Title VII.

Title VII consent decrees have all the commonplace virtues of settlements. A consent decree saves all concerned the potentially enormous costs in time, money, and emotional toll that might otherwise go

62. In the early years of antitrust consent decrees, courts were reluctant to tamper with a decree unless there was a "clear showing" that changed circumstances made it "grievously wrong" to carry on with the original decree. The emphasis was on the need for finality of judgment and, implicitly, on the idea that the parties should live with the agreement they make. See United States v. Swift \& Co., 402 U.S. 673, 681 (1971); see generally Note, Flexibility and Finality in Antitrust Consent Decrees, 80 Harv. L. REv. 1303, 1324-27 (1967); Note, Requests by the Government for Modification of Consent Decrees, 75 Y ALE L.J. 657, 658 (1966).

Several contemporary courts have explicitly recognized, however, that a public law consent decree is different in kind from a settlement that primarily affects only the parties. These courts have held that the entry of a civil rights consent decree should therefore be the beginning of an "ongoing remedial process." Sarabia v. Toledo Police Patrolman's Ass'n, 601 F.2d 914, 919 (6th Cir. 1979). On this view, a consent decree is a kind of "prediction" of what remedy will be socially effective, and the court should be available to modify it if it is not working. See Philadelphia Welfare Rights Org. v. Shapp, 602 F.2d 1114, 1121 (3d Cir. 1979), cert. denied, 444 U.S. 1026 (1980). See generally Fiss, Forms of Justice, supra note 2, at 49 (discussing need to revise consent decrees); see also Bolden v. Pennsylvania State Police, 73 F.R.D. 370, $371-74$ (E.D. Pa. 1976), (raising a consent decree's minority hiring quota from $33 \%$ to $50 \%$ and promotion quota from $25 \%$ to $33 \%$, because unforeseen budget cutbacks had drastically reduced the number of jobs being filled and little progress was therefore being made towards the decree's objective of integrating the State Police), affd, 578 F.2d 912 (3rd Cir. 1978). Cf. Firefighters Local Umion No. 1784 v. Stotts, 104 S. Ct. 2576 (1984) (holding that courts may not modify Title VII consent decrees to provide that lay-offs caused by budget restrictions must not reduce the proportion of minorities im any job category). Such a modification would require laying off whites with greater seniority in place of minorities hired more receutly under the affirmative action provisions of the consent decrce. The Supreme Court rejects dilution of seniority rights as incousistent with Section 703(h) of Title VIl, 42 U.S.C. $\$ 2000 \mathrm{e}-2(\mathrm{~h})$ (1982). See International Bhd. of Teanisters v. United States, 431 U.S. 324 (1977).

63. See, e.g., EEOC v. Bartenders Int'1 Umion Local 41, 28 Fair Emp. Prac. Cas. (BNA) 1575, 1576 (N.D. Cal. 1979) (extending the duration of the decree where neither the interim quotas nor the ultimate goal had been met). After a consent decree is entered, the court may still have a delicate job of manageinent: coordinating compliance by what is often a large and ramified institution, interpreting the decree as unforeseen problems arise, resolving disputes, and modifying the decree should circumstances change. See generally Diver, The Judge as Political Powerbroker, 65 VA. L. Rev. 43 (1979); Resnik, Managerial Judges, 96 HARv. L. Rev. 374 (1982).

64. See supra notes $35-42$ and accompanying text. 
mto large-scale Title VII litigation. ${ }^{65}$ Moreover, like any settlement, a consent decree is a coinpromise that spares all parties the risk of losing the case in a "winner-take-all" lawsuit. 66

Consent decrees are particularly compatible with structural public law cases. A reinedy designed to reform the workings of a large organization is unost effective when the organization cooperates im carrying out the remedy, and the liuman beings who make up an institution are more apt to cooperate im carrying out a negotiated scheme than in complying with an order imposed from above by a court. ${ }^{67}$ Public law settlements are often complicated documents designed to be carried out over a period of years, however, so any purely out-of-court settlement would suffer the decisive liandicap of not being subject to contimuing oversight and interpretation by the court. Courts are available to resolve disputes over the implementation of a consent decree, and may impose stiffer requirements if a defendant is not carrying out its obligations. ${ }^{68}$ Above all, a consent decree has the moral authority of a federal court order, witl disobedience pumisliable as contempt of court, and a defendant institution is subject to that order throughout the years that the decree is in effect. For all these reasons, consent decrees liave become a popular vehicle for public law remedies. ${ }^{69}$

Specific characteristics of Title VII also inake consent decrees attractive to parties and to the courts. From a defendant's viewpoint, a charge of einployment discrimination is often difficult to rebut. Once the plaimtiff shows statistically that minorities or women have not been hired or promoted in the proportion that they apply, the defendant can

65. These savings will vary, of course, with the content of the decree and the stage of the proceedings when it is signed. There is sometimes a partial consent decree, which resolves some issues and leaves others to be litigated. See, e.g., High v. Braniff Airways, Inc., 592 F.2d 1330, 1332 (5th Cir. 1979) (litigating small portion of a case otherwise settled in a massive consent decree). Moreover, a consent decree can be entered at any time from the filing of the coinplamt until final judgment is rendered. Obviously, a consent decree subinitted after the trial, but before the judgment, saves less time and trouble than does a decree submitted and approved earlier in the gaine.

66. A consent decree does not entail a finding of liabihity, so it has no collateral estoppel effect. Theoretically, a consent decree also has no stare decisis effect, although parties negotiating consent decrees tend to use existing decrees as models, so Title VII consent decrees lave come to bear a strong family resemblance to one another over time.

67. See Diver, supra note 63, at 90 (arguing that successful reform requires cooperation from those whose beliavior must be altered and therefore judicial remedies must be designed to assure active involvement of those affected).

68. A court may grant "supplemental rehef" when a party, usually the defendant, has failed to comply with the original consent decree. See United States v. City of Philadelphia, 499 F. Supp. 1196, 1202 (E.D. Pa. 1980); EEOC v. Bartenders Int'l Union Local 41, 28 Fair Empl. Prac. Cas. (BNA) 1575, 1577 (N.D. Cal. 1979).

69. For a further discussion of the relationship between consent decrees and public law, see infra notes 79-110 and accompanying text. 
defeat an inference of discrimination only by proving that there is a "valid business necessity" for the job prerequisite, written test, or oral interview that is responsible for the disproportionate results. Proving "business necessity" is often difficult to do.70 In addition, there is a stigma associated with being a defendant charged with race or sex discrimination, and litigation guarantees publicity. A defendantwhether a corporate employer or a public bureaucracy-may prefer a quick settlement to a well-publicized lawsuit.71

There is a more subtle factor that may make consent decrees attractive to Title VII plaintiffs. The Supreme Court has never explicitly upheld racial or sexual quotas as court-ordered remedies, ${ }^{72}$ and it remains controversial whether minority groups or women should receive preferential treatment by court decree. Plaintiffs in Title VII cases may sense that such "affirmative action" is inore readily acceptable to the courts and to society if it arises through negotiated compromise rather than through full-blown adversarial litigation. ${ }^{73}$

70. See supra note 22.

71. As in any public law case, the relief in a Title VII case will affect the employer's operations for years to come, so the defendant has a strong interest in participating as much as possible in formulating the decree. A defendant obviously has more say in negotiating a consent decree than in a court order handed down after it loses the case. Moreover, there is always the possibility that the employer, or at least some of the human beings who constitute that corporate entity, will feel that minorities were wrongly excluded from the staff or are too sparsely representcd on it; such an employer might simply wish to get on with a rcmedy.

72. See, e.g., Boston Chapter NAACP v. Beecher, 679 F.2d 965 (1st Cir. 1982), vacated as moot sub nom. Boston Firefighters Union, Local 718 v. Boston Claptcr, NAACP, 461 U.S. 477 (1983); United States v. City of Chicago, 549 F.2d 415 (7th Cir.), cert. denied, 434 U.S. 875 (1977). In United Steelworkers of America v. Weber, 443 U.S. 193, 200 (1979), the Court upheld an inplant training program in which half the places were reserved for black employees, but emphasized that this was a "voluntary" scheme, collectively bargamed by a private employer and a union and not created under court order. In Regents of the Univ. of Cal. v. Bakke, 438 U.S. 265 (1977), four Justices broadly approved "affirmative action" quotas and prefercnces for ininorities, four Justices said that the University's "affirmative action" policy excluded whites on the basis of their race and was therefore illegal, and Justice Powell's mdividual opinion became the judgment of the court, striking down the University's quota system but lolding that a school may take race into account in admittimg studeuts in order to encourage a "robust exchange of ideas" in the classroom. Id. at 313-24. Powell noted that the courts of appeals in employment discrimination cases "lave fashioned various types of racial preferences as remedies for coustitutional or statutory violations resulting in identified, race-based injuries to individuals held entitled to the preference." Id. at 301. In a footnote, he added that Bakke "does not call into question congressionally authorized administrative actions, such as consent decrees under Title VII . . ." Id. at 302 n.41. The significance of these dicta by one justice is debatable. See also Firefighters Local Union No. 1787 v. Stotts, 104 S. Ct. 2576, 2588-90 (1984) (suggesting that Title VII does not permit remcdial racial quotas and authorizes "relief only to those who have bccn actual victims of illegal discrimination").

73. Cf. United Steelworkers v. Weber, 443 U.S. 193, 201-02 (1979) (upholding "affirmative action" quotas negotiated privately, in the absence of any formal adjudication). A consent decree occupies a middle ground between a purely private batgain and a litigated court order. 
From the judge's poimt of view, of course, a consent decree saves an enormous amount of time and trouble ${ }^{74}$ a consent decree appeals to what might be called the "primciple of least judicial effort." Moreover, a judge quite properly encourages a settlement when it fosters a conciliatory atmosphere in which the employer is inore likely to comply with the letter and the spirit of the decree. ${ }^{75}$

Less creditably, perhaps, some judges inay welcome Title VII consent decrees as an opportunity to avoid grappling with the policy dilemmas and moral ambiguities lurking about "affirmative action." This article suggests, among other things, that consent decrees should not exempt the courts from considering the effects of negotiated decrees on those who are not parties to the negotiations. ${ }^{76}$

Federal courts have certainly been hospitable to Title VII consent decrees, and have interpreted Title VII itself to favor conciliation, voluntary compliance, and, by extension, consent decrees as a "preferred means" of resolving employment discrimination cases. ${ }^{77}$ In fact, Title VII consent decrees are approved in the overwhelming majority of cases in which they are submitted to federal judges. ${ }^{78}$

\section{Case Without Controversy}

By definition, a consent decree can come into force without a trial

74. See, e.g., United States v. Allegheny-Ludlum Indus., 517 F.2d 826, 851 n.28 (5th Cir. 1975) (speculating that trial on the merits could take 28 years), cert denied, 425 U.S. 944 (1976). Cf. United States v. Lee Way Motor Freight, Inc., 625 F.2d 918, 951 (10th Cir. 1979) (protracted Title VII litigation); United States v. City of Chicago, 549 F.2d 415, 421-25 (7th Cir.), cert. denied, 434 U.S. 875 (1977).

75. In public law litigation, even a decree in a contested case nuay to sonie extent be a negotiated affair. After the verdict is handed down, the court may ask the defendant as well as the plaintiff for a proposed order, and will usually try to develop a decree after taking account of all parties' concerns. See Diver, supra note 63, at 51-53 ("The decree [follows] an extended process [beginning] with a court order to the defendants to submit a comprehensive plan for the eradications of violations . . . ."). With a consent decree, of course, the parties assume even more of the responsibibity.

76. See infra notes 111-218 and acconpanying text.

77. See, e.g., United States v. Allegheny-Ludlum Indus., 517 F.2d 826, 847 (5th Cir. 1975) (quoting Alexander v. Gardner-Denver Co., 415 U.S. 36, 44 (1977) ("cooperation and voluntary compliance were . . . the preferred neans")) cert. denied, 425 U.S. 944 (1976).; see also Carson v. American Brands, Inc., 450 U.S. 79, 88 n.14 (1981); United States v. City of Miami, 664 F.2d 435, 442 (5th Cir. 1981); Flinn v. FMC Corp., 528 F.2d 1169, 1174 (4th Cir. 1975), cert. denied, 424 U.S. 967 (1976).

78. See, e.g., Williams v. City of New Orleans, 694 F.2d 987, 991 (5th Cir. 1982) (consent decrees enjoy presunption of validity im Title VII hitigation); United States v. City of Alexandria, 614 F.2d 1358, 1361 (5th Cir. 1980) ("district courts lave generally approved proposed settlements and appellate courts have only rarely reversed decisions approving settlements"). A district judge's refusal to enter a consent decree can be appealed immediately; the parties need not first hitigate the nerits of the case. See Carson v. American Brands, Inc., 450 U.S. 79, 83 (1981). 
and without judicial findings of fact and conclusions of law. ${ }^{79}$ This creates at least the appearance that consent decrees are jurisprudentially anomalous. To understand Title VII consent decrees, one must consider the apparent anomaly in the context of public law adjudication and its special needs.

Under Article III of the Constitution, federal courts may only decide "cases or controversies." 80 Courts have derived an intricate network of doctrines from the "case or controversy" requirement. ${ }^{81}$ These "justiciability" doctrines often have an air of scholastic theology about them, but at root they reflect the view that only certain decisions should be made by courts in a democratic society; other decisions should be made and disputes resolved-if at all-by nonjudicial institutions. ${ }^{82}$ This principle is near enough a platitude that it is accepted not only by "conservatives" who think that the proper business of the courts is traditional private law decisionmaking, ${ }^{83}$ but also by "liberals" who are favorably disposed toward lawsuits over public policy. ${ }^{84}$

One leitmotiv of the "case-or-controversy" requirement is that

79. Some consent decrees, of course, are submitted only after the trial has begun or even after the trial is over. See, e.g., United States v. County of Fairfax, 629 F.2d 932, 942 (4th Cir. 1980), cert. denied, 449 U.S. 1078 (1981). Even so, consent decrees are routinely entered before the parties ever come to court in conflict about the case.

80. See U.S. ConsT. art. III, cl. 2.

81. Compare Duke Power Co. v. Carolina Envtl. Study Group, 438 U.S. 59, $81-82$ (1978) (plaintiffs with environmental and aesthetic concerns have standing to challenge a law limiting liability of power utilities) with Simon v. Eastern Ky. Welfare Rights Org. 426 U.S. 26, 40-42 (1976) (indigents lack standing to challenge favorable tax treatment for hospitals that offer limited services for indigents); compare Warth v. Seldin, 422 U.S. 490, 499-500 (1975) (plaintiffs lack standing when their injury is speculative) with United States v. Students Challenging Regulatory Agency Procedures (SCRAP), 412 U.S. 669, 684-85 (1973) (public interest organization has standing despite "attenuated line of causation"); see also Linda R.S. v. Richard D., 410 U.S. 614, 617 (1973) (plaintiff must show "sufficient nexus" between injury and the challenged government action).

82. For a sample of recent scholarly comment on this inexhaustible topic, see generally Brilmayer, The Jurisprudence of Article III: Perspectives on the Case or Controversy Requirement, 93 HARV. L. Rev. 297 (1979); Davis, Standing: Taxpayers and Others, 35 U. CHI. L. REv. 601 (1968); Monaghan, Constitutional Adjudication: The Who and When, 82 YALE L.J. 1363 (1973); Tushnet, The Sociology of Article III: A Response to Professor Brilmayer, 93 HARV. L. REv. 1698 (1980) [hereinafter cited as Sociology of Article III]; Tushnet, The New Law of Standing: A Plea for Abandonment, 62 CORNELl L. REv. 663 (1977).

83. See Fuller, The Forms and Limits of Adjudication, 92 HARv. L. Rev. 353 (1978) (emphasizing a traditional view of the limits of litigation in a democracy).

84. See, e.g., K. Davis, Discretionary Justice passim (1969); L. Tribe, American Constrtutional LAW \& 3-21 (1978) (arguing for a broader view of justiciability). Even Professor Mark Tushnet, a stalwart of the "critical legal studies" unovement, seems to agree that parties should lave at least some minimal standing in order to meet the "case or controversy" requireinent. Tushnet, Sociology of Article III, supra note 82, at 1706. 
lawsuits in federal court should have "adverse" parties. ${ }^{85}$ The Supreine Court has said that federal courts should act only after hearing "a clash of adversary argument exploring every aspect of a multifaceted situation embracing conflicting and demanding interests." 86 Because judges, unlike congressional committees, traditionally have no independent means of fact-finding and must rely on the facts imtroduced into evidence by the parties, the "judicial process" itself is said to require adversary proceedings. Resolving contested disputes is what distinguishes the work of a court from the policymaking of an executive or legislative body. 87

If the role of the federal courts really were so neatly demarcated, and especially if Article III restricted the courts to deciding contested lawsuits, then consent decrees would be entirely anomalous. In fact, the courts traditionally issue orders in a variety of non-adversarial contexts. Kenneth Culp Davis poimted out a generation ago that the absence of any "controversy" does not prevent the federal courts from admittmg ahens to citizenship, issuing uncontested subpoenas, presidmg over uncontested bankruptcy proceedings, or disposing of criminal cases im which the defendant pleads guilty. ${ }^{88}$ It is widely accepted today that judicial functions overlap legislative, executive, administrative, and even private functions and that there is no uniquely "correct" forum-court, Congress, city council, Masomic lodge - in which any given family quarrel, zoning dispute, corporate reorganization, or alle-

85. The adversary system draws philosophical justification from John Stuart Mill's notion that truth is best sought through vigorous debate. J.S. MILL, On Liberty, in ON LIBERTY AND Considerations on Representative Government 1, 13-48 (R. McCallum ed. 1948); see Note, Judicial Determinations in Nonadversary Proceedings, 72 HARv. L. Rev. 723, 736 (1959) (noting Mill's emphasis on disputation and argument as means towards truth). But cf. J. STEPHEN, LIBERTY, EQUALITY, FRATERNITY passim (1873) (the classic Victorian rebuttal of Mill).

86. Flast v. Cohen, 392 U.S. 83, 97 (1967) (citing United States v. Fruehauf, 365 U.S. 146, 157 (1961)).

87. Justice Felix Frankfurter is particularly identified with this view of the role of federal courts in the constitutional scheme: "Regard for the separation of powers and for the importance to correct decision of adequate presentation of issues by clashing interests restricts the courts of the United States to issues presented in an adversary manner." Anti-Fascist Committee v. McGrath, 341 U.S. 123, 151 (1951) (Frankfurter, J., concurring) (citations omitted). See also Frankfurter, Advisory Opinion in I ENCLYCLOPEDIA OF THE SoCIAL SCIENCEs 475, 478 (1930) (discussing the disadvantages of advisory opimions); Moore v. Charlotte-Mecklenburg Bd. of Educ., 402 U.S. 47, $47-48$ (1970) (per curiam) ("We are . . . confronted with the anomaly that both litigants desire precisely the same result .... There is, therefore, no case or controversy within the meaning of Art. III of the Constitution.").

William Blake was evidently a Frankfurter nan: "Without Contraries is no progression." W. Blake, Marriage of Heaven and Hell, in Complete Writings of William Blake 149 (G. Keynes, ed. 1972).

88. $3 \mathrm{~K}$. DAVIS, supra note 34 , at $\$ 21: 01$. 
gation of employment discrimination must be resolved..$^{89}$

Accordingly, the Supreme Court upheld consent decrees long before there was any statutory basis for them.90 More recently, Congress has explicitly endorsed and regulated consent decrees in antitrust cases. ${ }^{91}$ Even in the absence of explicit legislation, courts continue to infer congressional approval for consent decrees in such areas as civil rights. Thus, the Supreme Court endorses Title VII consent decrees as consistent with the statute's preference for "voluntary settlement of employment discrimination claims." 92

The nature of public law or structural adjudication may actually make "adverseness" less important as a source of information for the courts than it is in the conventional tort or contract case. Courts traditionally rely on the parties to develop the "facts" of a case. At the outset of a trial the court is ignorant of events between the parties and each party attempts to establish its version of what occurred. This exercise in historical reconstruction is important precisely because the remedy, if any, will correspond closely to the cause of liability. The specifics of what the defendant did and the context $\mathrm{m}$ which he did it will establish whether he was negligent or whether he entered into an enforceable bargain; the plaintiff's actual losses will usually establish the basis for danages. This framework is admirably suited to traditional hitigation, but it has limited applicability to public law adjudication because there is a paradoxical sense in which the facts do not matter in a public law

89. See Cover, Dispute Resolution: A Foreword, 88 Yale L.J. 910, 910 (1979) (courts are merely one way of resolving disputes).

90. See United States v. Swift \& Co., 286 U.S. 106, 119 (1931) (upholding a consent decree in a suit brought by the United States under the Sherman Act). See also United States v. ITT Continental Baking Co., 420 U.S. 223, 243 (1975).

91. Antitrust Procedures \& Penalties Act, Pub. L. No. 93-528, 88 Stat. 1706, 1706-08 (1974) (codified as amended at 15 U.S.C. § 16(b)-(h) (1982)).

The requirement that parties be "adverse" is largely a matter of judicial self-restraint, although the Supreme Court has insisted that the "bare miniuna" for justiciability are required by Article III. See United States v. Richardson, 418 U.S. 166, 196 n.18 (1973) (Powell, J., concurring). Thus, were courts to reject consent decrees on "case-or-controversy" grounds when such decrees are authorized by statute, courts would have to declare then unconstitutional and not merely incompatible with the limitations "closely related to Article III concerns but essentially matters of judicial self-governance." Warth v. Seldin, 422 U.S. 490, 500 (1974). See Flast v. Cohen, 392 U.S. 83, 130-33 (1967) (Harlan, J., dissenting) (standing requirement imposed by Court upon itself to effectuate separation of powers); see also Ashwander v. Teunessee Valley Authority, 297 U.S. 288, 346-48 (1935) (Brandeis, J., concurring) (Court has developed a series of rules to avoid passing upon many of the constitutional questions with which it is presented).

92. Carson v. American Brands, Inc., 450 U.S. 79, 88 n.14 (1981); cf. Monaghan supra note 82, at 1376-77 (arguing that Congress should control the extent to which courts bypass the traditional justiciability rules in public law cases). The question remains, of course, how freely the courts may interpret acts of Congress as relaxing or tightening the traditional rules. 
case. They do not matter to the extent that the specifics of the remedy will not be decided on the basis of "what the defendant did."

In short, the choice of remedies in public law cases properly depends on "legislative facts" as much as on "adjudicative facts." The distinction is a familiar one. Adjudicative facts concern the past actions of the parties: "who did wliat, where, when, how, wlyy, with what motive or intent."93 Legislative facts are inore general judgmentsoften not conclusively provable - which courts use to "decide questions of law and policy and discretion."94 The significance of the distinction is that when courts decide "adjudicative facts" they inust generally do so on the basis of a trial.95 Legislative facts, on the other hand, are not necessarily litigated.96

In a Title VII case, adjudicative facts are not decisive to the extent that particular remedies do not follow from a finding that the employer discriminated. The specifics of the remedy will depend substantially on what the court thinks will be fair and effective in the future: whether a hiring or promotion quota is an appropriate vehicle for integration, how high the quota sliould be, how flexible, how mucl money should be spent on minority recruitment or traming, how inuch emphasis to put on "validating" the job qualifications. These judgments, obviously, cannot be made without knowing "facts" about the employer's business and the surrounding community, but most important are legislative facts concerning the present or the future, not the historical facts of hability which are the subject of conventional litigation. Similarly, the "law"-specifically the law dictating what remedies are appropriatedoes not entirely lend itself to adversary argument in Title VII cases, because the governing rule is that the court has broad remedial discretion..$^{97}$ Adversary argument is not necessarily the court's best source of guidance on how to exercise this discretion intelligently. Cloosing a remedy ainong inany possibilities, all of them perfectly "legal," is inore open-ended and less a matter of "right" or "wrong" than deciding how to apply a Uniforin Commercial Code provision or whether a tort pre-

93. $2 \mathrm{~K}$. Davis, supra note 34 , at $\$ 12: 3$.

94. Id. The distinction was first proposed in Davis, An Approach to Problems of Evidence in the Administrative Process, 55 HARv. L. REv. 364, 402-16 (1942).

95. "A party whose interest is protected by due process is entitled to opportunity for a trialtype hearing on disputed adjudicative facts." $2 \mathrm{~K}$. DAvis, supra note 34, at $\$ 12: 3$.

96. See Association of Nat'l Advertisers, Inc. v. FTC, 627 F.2d 1151, 1162 (D.C. Cir. 1979) (legislative facts "need not be developed through evidentiary hearings"), cert. denied, 447 U.S. 921 (1980); Alaska Airlines Inc. v. Civil Aeronautics Bd., 545 F.2d 194, 200 (D.C. Cir. 1976) (where the agency is involved in rule-making, rather than adjudication, no hearing is required).

97. See supra note 33 and accompanying text. 
cedent is distinguishable. ${ }^{98}$

Of course, one inust beware of exaggerating the distance between "public" litigation and the dowdy old "private" kind. Even the inost ordinary contract or trespass suit is fraught with presuppositions about "public" questions such as the right to property, the social sources and limits of individuals' rights to self-determination, and the relation of the individual to the State. ${ }^{99}$ In addition, the remedies in conteinporary public litigation are not completely unhinged from the adjudicative facts that inake for liability. If a Title VII defendant denies all wrongdoing, litigates, and wins, a court will not proceed to impose a remedial injunction anyway. Even where a defendant has been held liable, the courts must grapple with the question of how narrowly the remedy in an institutional case should be designed to correct the demonstrated historical violation, or, coming at it from the other direction, how broadly it should be designed to correct the social problems that formed the context of the violation. 100 In public law cases, the relationship of remedy to violation is anbiguous and indirect, but it is not entirely non-existent.

98. The courts therefore seek the cooperation of the parties in choosing workable remedies in public law cases. See Diver, supra note 63, at 62-64 (on the limits of the adversary model in institutioual litigation); see also Monaghan, supra note 82, at 1372-74 (where constitutional question turns on legislative facts, factual determination has little bearing on resolution).

99. See Jacobson, The Private Use of Public Authority: Sovereignty and Associations in the Common Law, 29 BuFFalo L. REv. 599, 600 (1980) ("theories . . . that divorce sovereignty from the daily business of private life are in error"). Courts have always had occasion to prescribe remedies that shape the future conduct of institutions as well as of individuals, with social ramifications affecting people who are not parties to the hitigation. See Eisenberg \& Yeazell, The Ordinary and the Extraordinary in Institutional Litigation, 93 HARv. L. REv. 465, 466 (1980) (suggesting that "institutional" adjudication is not so differeut from what courts have always done, and that it is an error to mistake new substantive rights for a completely new style of judicial behavior). One might add that law school casebooks are essentially anthologies of cases, beginning with Marbury v. Madison, 5 U.S. (1 Cranch) 137 (1803), that have public ramifications.

100. This dilemma is illustrated in several Suprene Court sclool desegregation decisions. In Dayton Bd. of Educ. v. Brinkman, 433 U.S. 406, 420 (1977), for example, the Court remanded the case to the district court to "determine low inuch increinental segregative effect the violations had on the racial distribution of the Dayton school population as presently constituted, whon that distribution is compared to what it would have been in the absence of such constitutional violations." The Court insisted that the remedy be narrowly designed "to redress that difference." Id. Yet in Milliken v. Bradley, 433 U.S. 267, 279-82 (1977), decided the same day, the Court prescribed "remedial" education programs that did not directly redress past segregation policies, and in later cases like Dayton Bd. of Educ. v. Brinkman, 443 U.S. 526, 529 (1979) and Columbus Bd. of Edue. v. Penick, 443 U.S. 449, 455 (1979), the Court approved system-wide desegregation plans that went beyoud the demonstrated violations by the defendants in those cases. See generally Fletcher, The Discretionary Constitution: Institutional Remedies and Judicial Legitimacy, 91 YALE L.J. 635, 679-83 (1982) (Brinkman and Milliken illustrate that the Court has not stated clearly how closely an injunctive remedy inust be tied to a constitutional violation). 
Nonetheless, perhaps the defining characteristic of public law litigation is its "legislative" flavor. Choices of public law remedies are heavily influenced by "legislative facts" concerning society and public policy. The remedies themselves have a broad public impact, extending far beyond the parties before the court, much in the style of public legislation. These "legislative" characteristics make public law adjudication anomalous by the yardstick of traditional private litigation. 101

Consent decree cases have all the anomalous characteristics of any pubhic law case, but in a more radical form. Public law cases are generally concerned not so much with liability as with questions of remedy that are only loosely related to the issue of the defendant's misdeeds; a consent decree requires no contested findings of fact. In public law cases the clash between the parties is usually somewhat blurred; a consent decree requires no adversary litigation. Any public law case is anomalously "political" because it requires discretionary policy decisions by the courts that might more conventionally be made by other branches of government. When approving a consent decree, the court actually delivers its power of institutional reform-and its discretion over the means of reform-to the parties who draft the agreement.

Title VII consent decrees are thus a double anomaly. Any Title VII remedy with elaborate "affirmative action" provisions is "political" because it embodies discretionary policy decisions about the future operations of an institution. This anomaly is compounded when the injunction has been written by the parties themselves, without adversarial presentation of the issues to the court, without trial, without findings of fact, and without conclusions of law.

An anomaly, even a double one, is not the end of the world. There is often an academic tendency to appraise public law adjudication by old-fashioned "private law" standards of tle judicial process, standards whicli never completely corresponded with the role of courts in American society. ${ }^{102}$ It is a fact that the courts are a forum for institutional change, and the federal courts in particular are an active part of the American political process. In such varied fields as antitrust, ${ }^{103}$ regu-

101. See supra notes 1-2.

102. See A. De Tocqueville, Democracy in America 140 (P. Bradley ed. 1946).

103. See, e.g. North Am. Tel. Ass'n v. United States, 460 U.S. 1001 (1983) (mem.), aff g United States v. American Tel. \& Tel. Co., 552 F. Supp. 131 (D.D.C. 1982). 
lated industries, ${ }^{104}$ the rights of prisoners ${ }^{105}$ and hospital patients, 106 school desegregation, ${ }^{107}$ and employinent discrimination, ${ }^{108}$ institutional policy decisions are routinely adopted through the judicial process. For institutional reforms to be carried out effectively under statutes like Title VII, consent decrees are indispensable because they lend the authority of the courts to prescriptions for institutional change without the massive costs of litigating each case. ${ }^{109}$

Nevertheless, concern about the substantive scope of public law adjudication and about the process by which it is conducted is not inere academic formalisin. The conventional wisdoin about the role of the courts rightly places a high value on rational decisionmaking based on due process and the application of articulated standards of substantive law. The nore public law adjudication adheres to these values, the less it can be attacked as illegitimate.

In appraising Title VII consent decrees with these values in mind, it is useful to distinguish between the procedure by which courts decide whether to sign consent decrees, and the substance of what is being signed. ${ }^{110}$ Procedural fairness requires that persons who will be affected by a decree should have a fair opportunity to be heard and that the court should have adequate information for its decision. A decree has substantive merit if what it requires is consistent with the policy of the law or, taking a broader view, if its prescriptions are moral and effective. This article will focus primarily on whether Title VII consent decrees are being approved in a way that is procedurally fair, and whether the fairness of the procedure might be improved.

104. See, e.g., Calvert Cliffs Coord. Comm. v. Atomic Energy Comm'n, 449 F.2d 1109 (D.C. Cir. 1971) (requiring regulatory commission to adopt detailed procedures to take environmental concerns into account when licensing nuclear reactors).

105. See, e.g., Procunier v. Martinez, 416 U.S. 396, 405-06 (1974) (modification of prison rules and practices to protect the prisoners' constitutional rights).

106. See, e.g., Youngber v. Romeo, 457 U.S. 307, 309-14 (1982) (patient in state mental hospital has rights to safe confinement, freedom from bodily restraint, and at least miminal training).

107. See, e.g., Swann v. Charlotte-Mecklenberg Bd. of Educ., 402 U.S. 1, 15.16, (1971) (court has discretion to shape a remedy for school desegregation plan); see also Brown v. Board of Educ., 349 U.S. 294, 300 (1954) (courts to consider such factors as school plant, personnel, and school district revision in considering desegregation plans).

108. See, e.g., Griggs v. Duke Power Co., 401 U.S. 424, 432 (1971) (employment standards that disproportionately screen out members of minority groups are nnacceptable, despite good intentions of employers).

109. See supra notes $65-69 \& 74$ and accompanying text.

110. Cf. Leff, Unconscionability and the Code-The Emperor's New Clause, 115 U. PA. L. REv. 485, 488 (1967) (analyzing the unconscionability clause of the Uniforn Commercial Code by distinguishing procedural unconscionability in the bargaining process from the substantive unconscionability of a harsh contract). 


\section{Procedural Fairness}

The problem of procedural fairness in consent decree cases stems from the fact that public law litigation typically affects a great many people who are not parties to the lawsuit. When a plaintiff and a defendant propose an institutional consent decree, they are asking the court for an unlitigated order that will affect a variety of interests in addition to their own.

\section{A. The Interests at Stake.}

In an employment discrimination case, most obviously, the interests of a minority group are at stake. A Title VII consent decree should improve employment opportunities for the minority group on whose behalf the lawsuit was brought. But a consent decree is not guaranteed to satisfy every member of the minority class; some members of the group might want a stronger remedy - a higher quota, perhaps, or more back pay. Moreover, a consent decree may emphasize one kind of relief over another. The stress might be on recruiting and hiring more members of the minority group; alternatively, it might be on traming and promoting those who have already been hired. ${ }^{111}$ Because a consent decree is a negotiated document, the employer will seldom agree to every conceivable remedial measure. Whatever the relative bargaiming strengths of the parties, employment pohicies can usually be reformed in any number of different ways, so the parties have considerable discretion to opt for one approach rather than another. ${ }^{112}$ Any consent decree is therefore hable to benefit some members of the minority group more-and others less-than would another possible decree.

It is not only the beneficiaries of a consent decree whose interests are at stake. A Title VII consent decree is likely to diminisli opportumties for white, or male, job applicants and employees. This is true of almost any form of "affirmative action." Whites suffer in a nebulous way when an employer merely agrees to recruit minority job applicants more mtensively, because the whites that now apply will have more

111. A practical dilemma that confronts civil rights lawyers is whether to press hardest for "retrospective" relief for individuals who were discriminated against by the employer-back pay and job offers with retroactive semority, for example-or whether to stress "prospective" neasures like hiring quotas and recruitment programs which benefit members of the minority group in general regardless of whether they were ever victimized by the employer.

112. The Reagan adininistration's distaste for quotas does not necessarily make it easier for the Justice Department to settle the Title VII suits that are still being brought by the Civil Rights Division. Some employers are less willing to sign consent decrees that emphasize "retrospective" relief, especially back pay, than they are to sign agreements calling for greater minority hiring in the future. This is because a decree emphasizing back pay usually has greater current out-ofpocket cost to the einployer. 
competition. A hiring quota affects whites more concretely, because some will be passed over who might otherwise be hired. Promotion quotas or changes in a seniority system are the most provocative kinds of relief: they can mean fewer promotions or more lay-offs for whites already on the employer's payroll.113 Moreover, a decree in favor of one minority group may diminish opportunities for other minority groups simply because the employer may give first priority to hiring or promoting the beneficiaries of the decree.

More generally, a Title VII consent decree affects the social fabric. It does so directly, by changing an institutional defendant's behavior; it does so indirectly to the extent that the decree is a precedent for future court orders 114 and to the extent that other employers change their personnel practices to conform to the court's order. ${ }^{115}$ Consent decrees also affect the economy, to the extent-probably unquantifiable-that reforms in personnel policy affect productivity.

All these interests are equally at stake, of course, when a plaintiff and a defendant litigate an imstitutional case and the court imposes its own remedy. The fact that a Title VII remedy may reduce the employment prospects of whites or males does not necessarily make the remedy improper. ${ }^{116}$ Moreover, some interests mevitably elude fornal representation in the courtroom: it is not easy, for example, to imagine the "social fabric" hiring a lawyer or filing an amicus brief. The question nonetheless is whether-and if so, how-persons who are not parties to the case but whose imterests are significantly affected should have a say in a consent decree, especially when the decree is entered without a trial of the facts and without the volley of arguments that might in a litigated lawsuit guide the court's sense of what remedies are appropriate.

113. Ironically, it is often the most marginal whites-cthose from circumstances least profiting froin the antecedent racisin in America"-who pay the price of affirmative action. See Van Alstyne, $A$ Preliminary Report on the Bakke Case, 64 A.A.U.P. Bul.. 286, 288 (1978).

114. See supra note 66.

115. The social fabric is unquestionably improved by bringing more members of a minority group into the inainstream of the econouny. There are also nore probleinatic consequences. Group reniedies such as quotas, for example, undoubtedly encourage a sense of group entitlement in society, and may foster the kind of social balkanization and interest group separatism that coexist uneasily with the American ethic of individual opportunity and with the ideal of national solidarity.

116. United States v. City of Alexandria, 614 F.2d 1358, 1366 (5th Cir. 1980) (approving consent decree giving hiring preferences to females and blacks); Unitcd States v. City of Jackson, 519 F.2d 1147, 1150 n.4 (5th Cir. 1975); see also United Steelworkers of America v. Weber, 443 U.S. 193, 208-09 (1979) (Supreme Court approved a 50\% minority quota in a company training program which was, however, adopted voluntarily and not under court order). 


\section{B. What the Courts Have Done.}

1. An Overview. The spectrum of possible procedures for approving a consent decree ranges from a compulsory trial of the case to an automatic "rubber stamp" approval of whatever settlement the parties might negotiate. Because consent decrees are an alternative to litigation, courts do not require full-fledged litigation of the defendant's hability as a prerequisite to a consent decree. ${ }^{117}$ In some cases, nonetheless, the parties actually negotiate their consent decree only after substantial litigation. ${ }^{118}$ At the other procedural extreme, courts often approve Title VII consent decrees without any formal proceedings whatever, and without affording any opportunity for nonparties to be heard. ${ }^{119}$

Instead of extensive hitigation or automatic approval of settlements, some courts have sought a middle ground by holding fairness hearings about proposed consent decrees. ${ }^{120}$ A fairness hearmg is a forum in which the participants can make suggestions about the settlement or object to its provisions, without enjoying the right to litigate the underlying liability of the defendant. Fairness hearmgs are reminiscent of the "notice-and-comment" procedure often required of federal administrative agencies in their rulemaking. ${ }^{121}$ Fairness hearings, like comments submitted to an administrative agency, are a counterpart to congressional committee hearings; they expose the court to a broader range of views concerning the policy choices embodied in a proposed decree and the likely consequences of those choices. When fairness hearings bring forth objections to a settlement proposal, the court generally states its reasons for accepting or rejecting the objections, just as administrative rulemakers must consider comments and give reasons for whatever rules are adopted.122

117. But cf. United States v. City of Miami, 664 F.2d 435 (5th Cir. 1981) (consent decree modified and in part vacated so as not to bind objecting third party), modifying, 614 F.2d 1322 (5th Cir. 1980), discussed infra at notes $188-97$ and accompanying text.

118. See infra notes 125-28 and accompanying text.

119. See infra notes 129-32 and accompanying text.

120. Sce, e.g., Metropolitan Housing Dev. Corp. v. Village of Arlington Heights, 616 F.2d 1006, 1014 (7th Cir. 1980) (trial court "need only determine that the settlement is fair, adequate, reasonable and appropriate"); Airline Stewards \& Stewardesses Assoc. v. American Airlines, 573 F.2d 960, 964 (7th Cir.) (per curiam) (trial court not required to litigate merits of Title VII settlement), cert. denied, 439 U.S. 876 (1978); Cotton v. Hinton, 559 F.2d 1326, 1330 (5th Cir. 1977).

121. See 5 U.S.C. $\$ 553$ (1982); (requiring notice and opportunity for "interested persons" to participate im agency rulennaking); see also $1 \mathrm{~K}$. DAvIs, supra note 34 , at $\S \S 6: 1-6: 2 ; c f . i d ., \S 6: 38$ (suggesting that courts have required far greater procedural fairness from administrative rulemakers than in their own policymaking).

122. After considering comments, an agency inust incorporate in its rules a "concise general statement of their basis and purpose." 5 U.S.C. § 553(c) (1982). See 1 K. DAVIS, supra note 34, at $\S 6: 2$ (explaining statute). 
When the parties to a class action propose a consent decree the court must give members of the plaintiff class an opportunity to appear at a fairness hearing before the decree can be approved. ${ }^{123}$ The courts have otherwise been erratic, however, about holding fairness hearings. There are often no hearings whatever in Title VII cases brought in the name of a federal agency rather than in the name of a private class. Even in class actions, courts often conduct fairness hearings only for class members, without providing any opportunity for participation by nonparties such as whites, or members of other minority groups not represented in the class, whose interests stand to be affected by the consent decree. ${ }^{124}$

2. Of "Litigated" Consent Decrees and "Rubber Stamps." When parties negotiate a consent decree after substantial litigation, or even after the court has been active in pretrial discovery, the judge's exposure to the case may approach what it would be in a fully litigated case. Thus, even though a court does not require litigation as a prerequisite to settlement, the judge's knowledge about the ramifications of a consent decree may depend on whether the decree is submitted early or late in the case. For example, in Officers for Justice v. Civil Service Commission, ${ }^{125}$ the parties submitted a consent decree to integrate the San Francisco Police Department six years after the plaimtiffs filed their complaint-after the court had ruled on the merits of four preliminary imjunction motions and one motion for partial suminary judgenent, after two weeks of trial, and after lengthy settlement negotiations which the court had directly supervised.126 The trial judge not only held fairness hearings concerning the consent decree, but was also able to appraise the decree on the basis of several years' acquaintance with the case and the parties, and im light of a substantial record and his own preliminary orders. In a sense, a case like Officers for Justice has the best of all worlds: the judge is well inforined about all the circumstances and he has a good basis for weighing the costs and benefits of various remedial measures, yet it is the parties who forinulate the decree; the federal judge need not unilaterally tell the City of San Fran-

123. See infra notes $133-43$ and accompanying text.

124. See infra notes $159-61$ and accompanying text.

125. 473 F. Supp. 801 (N.D. Cal. 1979), affd, 688 F.2d 615 (9th Cir. 1982), cert. denied, 459 U.S. 1217 (1983).

126. Officers for Justice, $688 \mathrm{~F} .2 \mathrm{~d}$ at $618-23$. The consent decree is set forth in Officers for Justice, 473 F. Supp. at 809-26. 
cisco how to run its police department. ${ }^{127}$ The trouble is that Officers for Justice required six years from the filing of the complaint to the entry of the consent decree. ${ }^{128}$

Conversely, im many imstances the parties negotiate a consent decree before a complaint is even filed; the parties submit their decree simultaneously with the filing of the complaint and the court promptly enters judgment without formal proceedings of any kind. In large-scale Title VII cases this can liappen when a government agency like the Justice Department or the EEOC is the plaintiff. In these situations the court knows nothing about the case or the context in which it is bemg settled and the judge relies on the assurances of the parties, especially the government agencies involved, that the consent decree is a Good Thing. ${ }^{129}$

This liappens fairly frequently, although there is usually no word of it in the official reports unless someone later goes to court seeking further action. Of the ninety-three Title VII consent decrees entered between the Justice Department and "public" employers-state or local governments-between 1972 and 1983, nearly a third were submitted together witl the coinplaimt and promptly signed by the court, usually on the same day. ${ }^{130}$ In a fairly typical imstance, United States $v$. City of Jackson, ${ }^{131}$ a decree with "wide-ranging injunctive relief"-including a fifty percent hiring "goal" for blacks, a thirty-three and onethird percent hiring "goal" for women, and accelerated promotions for black employees-was filed together with the complaint on a Friday and signed by the district judge the following Monday. ${ }^{132}$

127. See Fletcher, supra note 100, at 653-55 (arguing that courts should encourage institutional defendants, especially public agencies, to resolve their own remedial probleins instead of leaving things to the dikfat of the judge).

128. Officers for Justice, 688 F.2d at 619-23. For other Title VII cases in which consent decrees followed substantial litigation, see United States v. Fairfax County, 629 F.2d 932, 943 (4th Cir. 1980), cert. denied, 449 U.S. 1078 (1981); United States v. Fairfax County, C.A. 78-862A (E.D. Va. Apr. 29, 1982) (consent decree for $\$ 2.7$ million in back pay approved after trial and judgment for the defendants on the merits and reversal of that judgment by the court of appeals); Luevano v. Campbell, 93 F.R.D. 68, 72 (D.D.C. 1981) (consent decree restructuring professional hiring in the United States Civil Service entered after two years of hitigation and extensive formal discovery); Kuck v. Berkey Photo, 87 F.R.D. 75, 76-77 (S.D.N.Y. 1980) (a typical sex discrimination consent decree in a private class action, negotiated on the eve of trial after extensive discovery and after litigation of several notions imcluding one for summary judgment).

129. See W. Sellar \& R. Yeatman, 1066 and All That passim (1936).

130. Files inamtaimed at the United States Department of Justice corroborate these figures.

131. 519 F.2d 1147 (5th Cir. 1975).

132. Id. at 1149-50. The case reached the court of appeals because a local union, whose ineinbers were black, sued to block the consent decree on the grounds that the back pay provisions were inadequate. The trial court refused to allow the union to intervene, and the court of appeals affirmed because the consent decree expressly allowed dissatisfied blacks to decline back pay under the decree and to sue for a bigger award. See also United States v. City of Milwaukee, 395 
Approving consent decrees on the say-so of the parties would be understandable if the parties were the only ones with interests at stake. Public law cases, however, involve a great many other interests. By treating Title VII cases as conventional two-party lawsuits, nany courts fail to give third parties-minority and white-any chance to be heard.

This can be illustrated in somewhat inore detail by comparing Title VII class actions-in which at least the minority "beneficiaries" have soine chance to be heard before a consent decree is approvedwith lawsuits by government civil rights agencies in which consent decrees are often approved without any hearings whatsoever. As for white third parties-and minority groups other than the intended beneficiaries of the consent decree-they are often denied a hearing both in private class actions and in prosecutions by the federal government.

3. Procedural Fairness to Minorities. Before approving a consent decree in a Title VII class action, the trial judge nuust hold fairness hearings in which class ineinbers are invited to object or to comment on the proposed decree. This procedure does not give class ineinbers a right to hitigate the inerits of the case; it does, however, ensure interested class inembers a "day in court" to present their views on the remedies that have been negotiated on their behalf. When the federal government brings a Title VII suit and negotiates a consent decree, on the other hand, the minority "beneficiaries" are often given no opportunity to be heard on the adequacy of the remedy.

The formal difference between a class action and a lawsuit by a federal agency is that the members of a class are considered "parties" to the case whereas the beneficiaries of a government suit are not. In a public law case, however, this fornal distinction obscures nore that it reveals about the practical effects of a settlenent on the minority group in question.

In a private class action, every nnember of the class is by definition a party to the lawsuit, and the doctrine of res judicata binds all the parties to any judgment in the case. ${ }^{133}$ Because nembers of the class

F. Supp. 725, 726 (E.D. Wis. 1975) (noting that a Title VII consent decree governing the Milwaukee Fire Department was entcred on the same day the complaint was filed). Typical unreported consent decrees entered simultaneously with the complaint include United States v. Massachusetts State Police, C.A. No. 82-2716S (D. Mass. Sept. 16, 1982); United States v. City of Fort Lauderdale, C.A. No. 80-6289 (S.D. Fla. June 20, 1980).

133. See Dosier v. Miami Valley Broadcasting Co., 656 F.2d 1295, 1299 (9th Cir. 1981) (class meniber bound by class action judgment provided he was adequately represented); Fowler v. Birmingham News Co., 608 F.2d 1055, 1058 (5th Cir. 1979) (class action decree was final adjudication of all claims that were or might have been brought on behalf of class meniber); see generally 7A C. Wright \& A. Miller, Federal Practice aNd Procedure $\$ 1789$ (1972) (discussing the preclusive effect of judgments in Rule 23 actions). 
may have divergent interests, ${ }^{134}$ and because the lawyers representimg the class have interests of their own, the courts recognize the danger that a settlement might unfairly favor one seginent of the class at the expense of another, or even stint the class in favor of a more generous award of fees for the lawyers. The remedy for this is procedural. A class action cannot be settled without notifying the class ineinbers ${ }^{135}$ and giving them a chance to appear and object before the settlement becomes final. ${ }^{136}$

In practice, most class action consent decrees under Title VII are approved even when class members appear and state objections to the settleinent. In Officers for Justice, for example, the court approved an elaborate consent decree designed to integrate-racially, ethnically, and sexually - the San Francisco Police Departinent; the court entered the decree after considering and rejecting an objection by one of the eleven named plaintiffs that the settlement afforded insufficient rehef for the named plaintiffs. ${ }^{137}$ In the case involving the hiring test for the United States civil service (the PACE exam ${ }^{138}$ ) the court considered objections from 153 of the estimated 100,000 class inembers, but-encouraged by the fact that only a small fraction of the class objectedthe court approved the consent decree as a fair compromise that would create "substantial" opportunities for minorities seeking federal jobs. 139

134. See supra note 111 and accompanying text.

135. FED. R. Civ. P. 23(e).

136. See, e.g., Officers for Justice v. Civil Service Comm'n, 688 F.2d 615, 623-24 (9th Cir. 1982), cert. denied, 459 U.S. 1217 (1983); Mandujano v. Basic Vegetable Products, Inc., 541 F.2d 832, 835-36 (9th Cir. 1976) (court cannot reject objections without giving the objector an opportunity to be heard). See generally 7A C. WRIGHT \& A. MILLER, supra note 133, at $\$ 1797$ (discussing procedure for dismissal or compromise of class actions).

Civil rights class actions are generally brought under FED. R. CIv. P. 23(b)(2), which governs cases whose main thrust is for injunctive relief. See 7A C. WRIGHT \& A. MILLER, supra note 133, at $\S 1775$ (subdivision (b)(2) added to Rule 23 to facilitate class actions in civil rights area). A class member has no right to opt out of a class certified under Rule 23(b)(2). If the class member's objections fail to persuade the court not to enter a consent decree, the decree will bind the dissenting class member and he is precluded from seeking further relief. See Kincade v. General Tire and Rubber Co., 635 F.2d 501, 506-08 (5th Cir. 1981). Even if the class is certified under Rule 23(b)(3), which governs cases whose thrust is for noney damages, class members nuay be given one opportunity to opt out at the beginning of the case but not a second opportunity when the terms of a consent decree are announced. The logic is that consent decrees would be discouraged if the class members with the strongest claims could opt out and seek nore relief than the settlement compromise affords. Officers for Justice, 688 F.2d at 635 . Under either provision, then, a class member will be bound by a consent decree unless lie or she can convince the judge not to sign it.

137. 473 F. Supp. at 808.

138. Luevano v. Campbell, 93 F.R.D. 68 (D.D.C. 1981).

139. Id. at 87. In Cotton v. United States Pipe \& Foundry, 14 Fair Empl. Prac. Cas. (BNA) 326, 327-28 n.3 (N.D. Ala. 1975), aff'd sub nom. Cotton v. Hinton, 559 F.2d 1326 (5th Cir. 1977), the consent decree was approved over the objections of $24 \%$ of the class. The judge eniphasized 
Approval of class action consent decrees is not automatic, however, and objections from class members sometimes cause consent decrees to be disapproved. In Pettway v. American Cast Iron Pipe Co., 140 for example, the Fifth Circuit held that a district court may not ratify a back pay agreement negotiated by the lawyers for the class when all the named plaintiffs and seventy percent of the class inembers objected that the suin was inadequate. ${ }^{141}$ Similarly, the Sixth Circuit, in Franks $v$. Kroger, ${ }^{142}$ held it to be an abuse of discretion to enter a consent decree that provided cash settleinents to the named plaintiffs, substantial attorneys fees, and "little, if anything" for the class inembers. ${ }^{143}$

The class action procedure ensures that the minority class is notified of an impending consent decree, and, if neinbers of the class have objections, that the court will hear and consider their views. When the federal government sues to enforce Title VII, however, the employer and the federal agency inay negotiate, and the district court may approve, a consent decree without notice and without formal hearmgs of any kind. ${ }^{144}$ The logic of not holding hearings before approving a consent decree in this sort of case is that a suit by a federal agency formally "binds" no one but the government and the einployer being sued; theo-

that the decree was negotiated at arm's length after considerable informal discovery, and that in some respects the settlement went further than might the remedy in a comparable litigated case. Judge Pointer refused to award attorney fees to the unsuccessful objectors in Cotton, observing that "[t]hose disgruntled class members who were responsible for organizing the rally which produced the wealth of objectors to the compromise no doubt have skills which can be of assistance in raising the funds for compensating their counsel." Id. at 334.

See also Parker v. Anderson, 667 F.2d 1204, 1211 (5th Cir.), cert. denied, 459 U.S. 828 (1982) (affirming approval of a settlement which included nearly $\$ 1.5$ million in back pay and provided for affirmative action which would cost the employer another million dollars, despite objections to the settlement as inadequate by all but one of the eleven named plaimtiffs; the court found that the named plaintiffs were objecting to the settlement in order to hold the class loostage to their "exorbitant" individual claims); Bryan v. Pittsburgh Plate Glass Co., 494 F.2d 799, 801-02 \& n.3 (3rd Cir. 1974), cert. denied, 419 U.S. 900 (1974) (affirming approval of a settlement despite objections by inore than $20 \%$ of the class that the decree gave them "a very small percentage" of their claim for back pay; approving the compromise, the court noted that the plaintiffs did not file timely charges and the court speculated, not entirely persuasively, that the plaintiffs might have had difficulty proving discrimination); Alaniz v. California Processors lnc., 73 F.R.D. 269, 288-89 (N.D. Cal.) (allowing dissenting class inembers to participate in the licaring whicli preceded entry of the consent decree, and explaining why their objections lacked merit, but refusing to let them intervene as full-fledged parties to the lawsuit), modified, 73 F.R.D. 289 (N.D. Cal. 1976), aff $d$ sub nom Alaniz v. Tillie Lewis Foods, 572 F.2d 657 (9th Cir.), cert. denied, 439 U.S. 837 (1978).

140. 576 F.2d 1157 (5th Cir. 1978), cert. denied, 439 U.S. 115 (1979).

141. Id. at 1213-18.

142. 649 F.2d 1216 (6th Cir. 1981).

143. Id. at 1226. The trial judge in Franks had rejected a previous settlement proposal after class members objected that it was inadequate. Id. at 1218-19. See also Mandujano v. Basic Vegetable Products, Inc., 541 F.2d 832, 835 (9th Cir. 1976) (requiring the district court to consider the objections of dissenters).

144. See supra notes $129-32$ and accompanying text. 
retically, the consent decree does not preclude members of the minority group froin bringing their own lawsuit and seeking greater relief. ${ }^{145}$

Yet once there is a consent decree in a government Title VII case, it is typically the only relief that the minority group will obtain from the employer. When a consent decree is adopted to restructure employment policies in a particular way, the parties-as well as the courts-grow institutionally committed to it. This commitment is reinforced rather than weakened by the fact that the parties might have adopted either a more radical or a gentler remedial sclieme. Precisely because discretionary choices are the hallmark of a public law decree, the courts and the parties are inclined to stand by whatever clioices they have actually made. For an individual to fight on for more relief after a consent decree has been approved is likely to be lonely, expensive, and futile. ${ }^{146}$

A person who files a discrimination complaint with the EEOC may be left in the saine procedural lurcl as the beneficiary of a government "pattern-or-practice" suit. The EEOC can sue under Section 706 of Title VII on behalf of individuals who have filed discrimination charges with the Commission. ${ }^{147}$ Unlike the Justice Department, the EEOC seldom brings "pattern-or-practice" cases under Section 707; instead, the Commission often sues for generalized and prospective rehef-essentially imstitutional reforin-on the basis of individual charges under Section 706. The Supreme Court has lield that the Commission can do this without complying with the rules for class actions. ${ }^{148}$ The "charging party" - the individual who filed the administrative complaint - can intervene in such a lawsuit while it is pending, ${ }^{149}$ but there is no requirement of notice to the class, and often the EEOC does not even inform the charging party when it files suit or

145. See United States v. City of Jackson, 519 F.2d 1147, 1152 (5th Cir. 1975) (the court noted, but was not swayed by, two practical problems: the consent decree might influence any back pay awards in subsequent lawsuits by black individuals, and private lawsuits might in any event be economically unfeasible once the class of potential plaintiffs was reduced by those who would "opt for an immediate payoff" under the consent decree).

146. See, e.g., United States v. South Bend Community School Corp., 710 F.2d 394 (7th Cir. 1983) (disinissing a inotion to intervene by a predominantly black group of parents objecting to a school desegregation consent decree negotiated by the federal government). The parents filed a separate lawsuit against the school district after it had entered into the consent decree, but the parents later conseuted "to have their complaint treated as a motion to intervene in the Justice Department's suit." Id. at 395.

147. 42 U.S.C. $\S 2000 \mathrm{e}-5(f)(1)$ (1982).

148. See General Tel. Co. v. EEOC, 446 U.S. 318, 333-34 (1980) (interpreting section 706(f)(1) of Title VII of Civil Rights Act of 1964, 42 U.S.C. $\S 2000 \mathrm{e}-5(f)(1)(1982)$ ).

149. 42 U.S.C. $\$ 2000 \mathrm{e}-5(f)(1)(1982)$. 
when it negotiates a consent decree. ${ }^{150}$

In other words, the EEOC is free to negotiate, and the court may approve, a consent decree without hearing from either the charging party or the intended class of beneficiaries. What is more, the charging party is considered a "party" to the lawsuit and is precluded by res judicata from seeking further rehef. Unless he or she has taken the initiative to mtervene and participate directly in the settlement negotiations - often without having been notified of the right to do so, or even that there is a lawsuit pending-the Commission has a free hand to negotiate a consent decree. The decree may mclude inadequate or nonexistent rehef for the charging party, and he or she is simply out of luck. ${ }^{151}$ If the decree is designed to prevent discrimmation $\mathrm{m}$ the future, the general class of minority or women beneficiaries is in the same position as its counterpart in a Justice Department "pattern-or-practice" suit: unlike the charging party, these people are not technically "bound" by the consent decree, but neither need they be notified or given an opportunity to object.

When government civil rights agencies negotiate consent decrees, the willingness of the courts to grant what amounts to automatic approval may be due to an assumption that the federal government acts in the pubhic interest. With the best will in the world, however, federal agencies have their own political and institutional agendas to consider. The Justice Department, for example, is an arm of the executive branch of government, and it has been the pohicy of the Reagan admmistration to oppose "affirmative action" quotas and not to negotiate consent decrees with quota provisions. ${ }^{152}$ A government consent decree, at least in this important respect, is therefore apt to differ from the remedy that private plaintiffs might seek in a Title VII case. The EEOC, for its part, has a notorious backlog of cases and charges, which can crcate pressure to settle more readily than would private plamtiffs. ${ }^{153}$

150. See Adams v. Proctor \& Gamble Mfg. Co., 697 F.2d 582, 585 (4th Cir. 1983) (Phillips, J., dissenting) (EEOC does not consider itself under obligation to keep "charging parties" apprised of settlement negotiations); McClain v. Wagner Elec. Corp., 550 F.2d 1115, 1119 (8th Cir. 1977).

151. Incredible, but true, at least in the Fourth Circuit: "If [the charging party] does not intervene and leaves it to the EEOC to do whatever seems best to the EEOC for him, he should not be heard to complaim of the consequences of his own indifference." Adams v. Proctor \& Gamble Mfg. Co., 697 F.2d 582, 584 (4th Cir. 1981). But see McClain v. Wagner Elec. Co., 550 F.2d 1115, 1121 (8th Cir. 1977) ("We do not think, however, that Congress intended by its enactment to create a situation in which an individual employee without fault or lack of diligence. . . might find himself unable to file his own suit or to intervene in a suit filed by the Commission.").

152. See supra note 53.

153. See Occidental Life Ins. Co. v. EEOC, 432 U.S. 355, 369 (1977) (discussing backlog of EEOC cases). 
When a judge signs a government consent decree without notice or hearing, then, the putative beneficiaries do not have an opportunity to review the impending decree and to object if they think it insufficient. Yet the scope of such a decree is often indistinguishable froin a class action settleinent. Of course, the "class" is theoretically not "bound" in a government case because there is res judicata only as between the government and the employer. The realities of institutional litigation, however, reduce the importance of this distinction. The beneficiaries of a class action have a chance to be heard before they are bound by a consent decree. The courts often neglect to give the beneficiaries of a government suit the same opportunity. ${ }^{154}$

\section{Procedural Fairness to Whites. By creating job opportunities} for minorities or women, a Title VII consent decree usually ineans fewer opportunities for whites or inen. ${ }^{155}$ Nonetheless, courts frequently deny white third parties any opportunity to be heard before a consent decree is approved. The implicit motive for denying whites a hearing is the fear that their participation might prevent consensual settlements, or at least delay thein significantly. This would be a legitimate fear if hearings for whites gave them the right to insist on litigation as a prerequisite to carrying out Title VII reinedies. Yet the only justification for refusing to histen to whites who will be affected by a consent decree is the fiction that a public law case is like a conventional lawsuit that concerns only the named parties. Only in a few cases have courts permitted white third parties to participate in fairness learings ${ }^{156}$

In Title VII suits mitiated by the federal government, as noted previously, consent decrees are often approved without advance notice and without the court hearing from anyone-minority or white-other than the litigants. ${ }^{157}$ In a class action, on the other hand, the court

154. See, e.g., United States v. Allegheny-Ludlum Indus., 517 F.2d 826, 842-46 (5th Cir. 1975) (announcing that an organization representing minorities and women has no standing to object to the sufficiency of a consent decree in a suit by the federal government, but considering at great length the objections of the organization to the merits of the decree), cert. denied, 425 U.S. 944 (1976).

See also Officers for Justice v. Civil Serv. Comm'n, 688 F.2d 615 (9th Cir. 1982), cert. denied, 103 S. Ct. 1219 (1983) (simultaneous Justice Department and class action lawsuit); Blake v. City of Los Angeles, 595 F.2d 1367 (9th Cir. 1979), cert. denied, 446 U.S. 928 (1980). When a jomt consent decree is negotiated in such a case the beneficiaries have notice and an opportunity to object as nembers of the class.

155. The interests of various minority groups inay also suffer.

156. See infra notes $174-87$ and accompanying text.

157. In these cases, minorities may have no chance to protest to the court about an inadequate decree. See supra notes 126-32 and accompanying text. 
cannot approve a consent decree until the members of the class have been notified and given a chance to object. While Federal Rule of Civil Procedure 23 does not require formal notice to anyone other than members of the plaintiff class, as a practical matter the notification of a minority group usually means that the defendant's white employees will also find out about the decree. ${ }^{158}$ Courts, however, have not been consistent in their treatment of whites who seek a hearing before the decree is approved. When they are denied a hearmg in a Title VII class action, it is usually on the pretext that their effort to intervene is "untimely."

In Culbreath v. Dukakis, 159 for example, the First Circuit affirmed a refusal to allow labor unions, whose members were mostly white, to intervene in a Title VII class action against various Massachusetts state agencies. One union moved to intervene one nonth before the plaintiffs and the state submitted their consent decree; three other unions followed after publication of the settlement proposal. The consent decree effectively nnposed a fifty-percent minority quota on hiring and on certam prolnotions. The lawsuit had been pending for more than four years and the district court ruled the intervention motions untimely. The court reasoned that the unions should have known all along that the suit was pending and that the plaintiffs' ultinnate objective was that minorities should be einployed by the state agencies im proportion to the local minority population. ${ }^{160}$ The unions' interest should thus have been "obvious" from the beginning, and the "expansion of rehef" was "a inatter of degree, not of kind." 161

158. In some cases the courts have required that notice of a proposed decree be posted pubhicly at the employer's workplaces. See, e.g., Alaniz v. California Processors Inc., 73 F.R.D. 269, 274 (N.D. Cal.), modified, 73 F.R.D. 289 (N.D. Cal. 1976), affd sub nom. Alaniz v. Tillie Lewis Foods, 572 F.2d 657 (9th Cir.), cert. denied, 439 U.S. 837 (1978).

159. 630 F.2d 15 (lst Cir. 1980).

160. Id. at $20-21$.

16I. Id at 21. Accord, Stotts v. Memphis Fire Dep't, 679 F.2d 579 (6th Cir.), cert. denied, 459 U.S. 969 (1982). For an extreme case, see McPherson v. School District No. 186, 33 Fed. R. Serv. 2d (Callaghan) 978, 979 (C.D. Ill. 1981) in which the judge modified a seven-year-old consent decree by forbidding lay-offs by semiority; the court rejected as untimely the efforts by a union to intervene in the modification proceedings because the union members should have foreseen before the decree was approved that it might later be modified to affect their interests. See also Commonwealth v. Rizzo, 530 F.2d 501, 507 (3rd Cir.) (im light of the extensive media coverage of the hitigation, appellants should have been aware that their interests were inphicated), cert. denied, 426 U.S. 921 (1976). Cf. Alaniz v. California Processors Inc., 73 F.R.D. 289, 294 (N.D. Cal. 1976) (untimely to intervene after entry of consent decree because there had been extensive noticc and opportanity to be heard before entry of the decree), aff'd sub nom., Alaniz v. Tillie Lewis Foods, 572 F.2d 657 (9th Cir.), cert. denied, 439 U.S. 837 (I978). Accord Smith v. Missouri Pacific R.R. Co., 615 F.2d 683, 685 (5th Cir. 1980) (1mtimely to intervene after entry of consent decree because there was notice of the suit and an imvitation to imtervene). 
This view is unrealistic in several ways. At the outset of a Title VII suit, white employees have no way of knowing whether their employer will decide to settle after several years instead of continumg to hitigate. The whites can fairly say, "We didn't intervene when the parties were at each others' throats because we were relying on our employer to defend the status quo. We moved to intervene promptly when we found out our boss was throwing in the towel." It is especially unrealistic to say that the whites should have known from the outset that any rehef might be at their expense, and that it is only "a matter of degree" if the decree is unexpectedly costly to their interests. The essence of institutional litigation is that the remedy cannot be deduced from the defendant's liability; the remedy embodies discretionary policy choices about the future operation of an imstitution. The variety of remedial possibilities in any given case makes it difficult to foresee which remedies the court or the parties will actually select. Potential intervenors cannot very well judge whether their interests are in serious jeopardy until they know what particular remedies are being contenplated. The unions in Culbreath moved to intervene when the terms of the settlement proposal became known. By dismissing their objections as untimely, the court punished thein for failing to foresee the unforeseeable. A hint in the Culbreath decision may explain the reluctance of many courts to listen to whites who will be affected by consent decrees: "There is a distinct probability that the intervention of the unions will destroy the consent decree and force a trial on the merits." 162

Indeed, if giving the objectors a hearing means letting thein intervene, and if intervention means the right to veto the settlement, then the courts have a tremendous incentive not to give the objectors a hearing. Once a party lias imtervened as a plaintiff or defendant in a conventional lawsuit, he or she is entitled to hitigate fully the merits of the case. ${ }^{163}$ Sucl an intervenor can nullify a consent decree by refusing to consent to it. Given the courts' strong preference for the settleinent of difficult public litigation, and the special emphasis on "conciliation" and settlement in Title VII cases, ${ }^{164}$ it would be understandable for the courts not to listen to third parties rather than to give them veto power over consent decrees. ${ }^{165}$

162. Culbreath v. Dukakis, 630 F.2d 15, 22 (Ist Cir. 1980). See also Stotts v. Memphis Fire Dep't, 679 F.2d 579, 584 (6th Cir.) (" $[$ t $]$ he prospect of delaying the 1980 Decree while the proposed intervenors engaged in additional discovery and expert analysis" was "correctly" a factor in denying intervention), cert. denied, 459 U.S. 969 (1982).

163. See 3B J. Moore \& J. Kennedy, Moore's Federal Practice ๆ 24.16[1] (2d ed. 1982).

164. See supra notes $77-78$ and accompanying text.

165. White einployees might have an imterest in delaying a reunedy even if they will eventually lose on the merits: while hitigation continues, promotions and assignments can still be made in the 
The effect of denying third parties a hearing on a proposed consent decree is especially dramatic, however, because many courts refuse to hear subsequent challenges to a consent decree once it has been entered. For example, the courts peremptorily rejected as an impermissible "collateral attack" a lawsuit by white males challenging the quota provisions of the consent decree in United States $v$. City of Jackson. ${ }^{166}$ The logic of the courts" hostility to "collateral attacks" is that settlements would be discouraged if they lacked finality, especially if einployers were vulnerable to "reverse discrimination" suits for complying with consent decrees. ${ }^{167}$ It seems reasonable that an einployer should not be subject to damage suits for obeying a consent judginent, but third parties are in an impossible bind if they are given no opportunity to inform the court of their interests before a consent decree is entered and if subsequent efforts on their part to modify the decree are dismissed as "collateral attacks."

One solution, of course, would be to abandon the idea that collateral attacks are impermissible. In their dissent from the denial of certiorari in City of Jackson, Justices Rehnquist and Brennan suggest as nuch. ${ }^{168}$ Finding themselves "at a loss" to understand the origin of the collateral attack doctrine, they argue that a consent decree "binds the signatories, but cannot be used as a shield against all future suits by nonparties seeking to challenge conduct that may or may not be governed by the decree."169 Permitting collateral attacks, however, would

old way, and whatever Title VII remedy is finally imposed, courts are reluctant to dismiss anyone from a job he or she actually occupies. See United Steelworkers v. Weber, 443 U.S. 193, 208 (1979) (upholding affirmative action plan where it did not require the discharge of white workers).

166. Thaggard v. City of Jackson, 687 F.2d 66, 68 (5th Cir. 1982), cert. denied, 104 S. Ct. 255 (1983). The district court rejected these white plaintiff' motion to intervene in the original action after the consent decree was entered. Ashley v. City of Jackson, 19 Fair Einpl. Prac. Cas. (BNA) 954, 955 n.2 (S.D. Miss. 1978), affd sub nom., Thaggard v. City of Jackson, 618 F.2d 272 (5th Cir. 1980) (per curiam), vacated, 642 F.2d 97 (5th Cir. 1981), affd, 687 F.2d 66 (5th Cir. 1982), cert. denied, 104 S. Ct. 255 (1983).

167. See Dennison v. City of Los Angeles Dep't of Water \& Power, 658 F.2d 694, 696 (9th Cir. 1981) (lawsuit against employer on behalf of white males seeking coinpensation for "reverse discrimination" dismissed as an impermissible collateral attack on the consent decree); see also Note, The Employer's Dilemma: Quotas, Reverse Discrimination, and Voluntary Compliance, 8 LoY. U. CHI. L.J. 369, 371, 388-89 (1977) (pointing out that einployers would be in a "Catch-22" position if they were hable both for discrimination and for "affirmative action" reverse discrimination). But cf. W.R. Grace v. Local Union 759, 103 S. Ct. 2177, 2186 (1983) (union may bring subsequent challenge against an EEOC conciliation agreement which-unlike a consent decree-is a settlement not entered as a judgment by a court); MeAleer v. American Tel. \& Tel. Co., 416 F. Supp. 435, 440 (D.D.C. 1976) (an atypical decision by a district court, refusing to dismiss a "collateral attack" and reasoning that the employer inight properly be held hable both for its original discrimination and for its subsequent remedial "reverse discrimination").

168. See supra note 15 and accompanying text.

169. Ashley v. City of Jackson, 104 S. Ct. 255, 257 (1983) (Rehnquist, J., dissenting). 
have ominous implications for consent decrees. The prospect of "reverse discrimination" litigation would certainly reduce the incentive for an employer to agree to an "affirmative action" decree. It is not even clear what would be litigated in the subsequent lawsuit. A logical approach would be for those challenging the decree to try to disprove the employer's liability under Title VII. But the parties to a consent decree usually agree to a settlement precisely in order to avoid litigation of liability. For this reason, the courts generally deny full-fledged intervention to white third parties before a decree is approved, in order to encourage settlement rather than litigation of the employer's liability. ${ }^{170}$ If collateral attacks were permitted, these public law cases would be subject to litigation on their merits-but after the entry of judgment instead of before the verdict. ${ }^{171}$

Fortunately, there is another possibility that fits the needs of public law adjudication. The court can grant limited intervention to third parties before approving a consent decree, without giving the intervenors the status of full-fledged litigants. ${ }^{172}$ Limited intervention means a day in court to argue whether the terms of a consent decree are reasonable, or to suggest alternatives and modifications. This kind of intervention helps the court to inake an informed judgment about the consent decree, without giving the intervenors a license to scuttle the decree or to delay relief by litigating the question of the defendant's liability. Restricting the terms of intervention-not permitting the intervenors to litigate the employer's liability-is consistent with the attenuated relation of reinedy to liability that is characteristic of public law. Limited intervention is a vehicle for interested third parties to cominent on a proposed decree without being permitted to shift the court's attention away from the remedy and back to the violation. ${ }^{173}$

This was the approach taken in Kirkland v. New York State De-

170. See United States v. Jefferson County, 720 F.2d 1511, 1518-19 (11th Cir. 1983) (expressing doubt about the collateral attack doctrine but refusing to allow white third parties to intervene and litigate before the decree is cntered).

171. "'Let the jury consider their verdict,' the King said, for about the twentieth time that day. 'No no!' said the Queen. 'Sentence first-verdict afterwards.' " L. CARROLL, ALICE's ADVENTURES IN WONDERLAND 160-61, (M. Gardner ed. 1960).

172. See FED. R. Crv. P. 24 advisory committee note (1966). ("An intervention of right under the anended rule nay be subject to appropriate conditions or restrictions responsive among other things to the requirements of efficient conduet of the proceedings."); see also 3B J. MOORE \& J. KenNedy, Moore's Federal Practice [f 24.10[4] (2d ed. 1982) (on restricting the scope of permissive intervention); see generally Shapiro, Some Thoughts on Intervention Before Courts, Agencies, and Arbitrators, 81 HARv. L. REv. 721 (1968) (litigation rights of an intervenor need not be as full as the rights of original parties but should be tailored to inatch the reasons for allowing the intervention).

173. For a discussion of the drawbacks of "limited intervention," see infra notes 214-17 and accoinpanying text. 
partment of Correctional Services, ${ }^{174}$ a Title VII class action challenging the state's civil service examinations in hight of their racial impact on proinotions. The plaintiffs and the state agreed to a consent decree which required, im effect, a short-term twenty-percent promotion quota for minority officers and a reform of promotional testing in the future. The court published notice of the settleinent proposal, and two groups of white officers moved to intervene.

The district court granted intervention "solely for the purpose of objectimg to the proposed settleinent."175 The imtervenors argued that the racial preferences in the decree were improper, and that in any event there should be no "affirmative action" remedy without a trial and a judicial determination that the employer violated Title VII. The court rejected the notion that the intervenors could litigate the employer's hability or compel the defendants to do so. Instead, the court analyzed the consent decree carefully, ${ }^{176}$ observed that the past systein of promoting employees in strict order of exam grades made meaningless differentiations among the candidates, ${ }^{177}$ and emphasized that the racial preferences in the decree were temporary and did not require the promotion of unqualified minorities or bar the proinotion of whites. 178 The court noted that it would not approve job preferences for minorities unless the plaintiffs had at least a serious claim of racial discrimination, but observed that in this case there were uncontested statistics mdicating that disproportionately few blacks or hispanics had been promoted. Because such statistics constitute a prima facie case of discrimination, 179 the court approved the consent decree without a trial of the einployer's liability. 180

Similarly, in Stallworth v. Monsanto, ${ }^{181}$ the Fifth Circuit recognized that it is unreasonable to deny third parties a hearing when they

174. 552 F. Supp. 667 (S.D.N.Y. 1982), affd, 711 F.2d 1117 (2d Cir. 1983).

175. Id. at 668 .

176. Id. at $670-71$.

177. Id. at $671-72$.

178. Id. at 676-77.

179. Id. (citing Texas Dep't of Community Affairs v. Burdine, 450 U.S. 248, 253-54 (1981)).

180. Kirkland, 552 F. Supp. at 675. See also Bolden v. Pennsylvania State Police, 73 F.R.D. 370, 373 (E.D. Pa. 1976) (white intervenors did not dispute defendant's liability but sought modifications in the consent decree), affd, 578 F.2d 912 (3rd Cir. 1978). Accord Dawson v. Pastrick, 600 F.2d 70 (7th Cir. 1979); Vulcan Soc'y v. Fire Dep't of White Plains, 505 F. Supp. 955 (S.D.N.Y. 1981); see also United States v. Allegheny-Ludlum Indus., 517 F.2d 826, 845 n.20 (5th Cir. 1975) (suggesting that unions be allowed "to intervene in the settlement formalization proceedings"), cert. denied, 425 U.S. 944 (1976); Alaniz v. California Processors, Inc. 73 F.R.D. 269, 274 (N.D. Cal.) (minority intervenors permitted to enter the case solely for the purpose of participating in a lhearing on the adequacy of a consent decree), modified, 73 F.R.D. 289 (N.D. Cal. 1976), affd sub nom, Alaniz v. Tillie Lewis Foods, 572 F.2d 65 (9th Cir.), cert. denied, 439 U.S. 837 (1978).

181. 558 F.2d 257 (5th Cir. 1977). 
offer their objections promptly after the parties propose a consent decree. Stallworth was a class action by black employees challenging, among other things, Monsanto's use of "departmental" semority for promotions, assignments, and lay-offs. (Blacks tended to have low seniority in the desirable departments. $)^{182}$ Two years after the suit was filed, the plaimtiffs and the company agreed to a consent decree that abolished the departmental semority system. ${ }^{183}$ The district court approved the settlement the day it was submitted. One month later a group of white employees moved to intervene. The district court rejected the intervention as untimely. The court of appeals reversed, reasoning that the whites acted promptly when they learned of the consent decree and discovered how seriously their interests were at stake. ${ }^{184}$ If they were required to intervene at the outset of the case, "when they ordinarily can possess only a small amount of information concerning the character and possible ramifications of the lawsuit," it would create a high "probability that they will misjudge the need for imtervention." 185 The case was remanded for the trial court to hear the white intervenors. 186

A hearing for the current employees or their unions does not, of course, ensure any representation for the interests of those who might apply for jobs in the future. People who may soine day apply for a job are not likely to be aware of it at the time a consent decree is being considered; they are in no position to learn about the settlement from their co-workers, nor are they especially apt to pay attention to publicity about an impending decree. They are, moreover, not an organized group. Accordingly, they cannot be expected to appear and speak up for their interests before the decree goes into effect. The interests of prospective job applicants from the plaintiff class are represented in a class action by the named plaintiffs. Before approving a remedy that will affect future hiring, therefore, a court occasionally permits a union-whose inembers are already on the job-to speak for prospective white applicants. When a plaintiff and an employer are in agreement on such a consent decree, and future white applicants are too isolated and too unaware to come and speak for themselves, the argu-

182. Id. at 260.

183. Id. at 261.

184. Id. at 267.

185. Id. at 265.

186. Id. at 261. See also Dawson v. Pastrick, 600 F.2d 70, 75 (7th Cir. 1979) (white union's objections considered, although consent decree reviewed deferentially and upheld on the merits); Mandujano v. Basic Vegetable Products, Inc., 541 F.2d 832, 837 (9th Cir. 1976) (remanding to the district court because the consent decree was approved without proper notice to the minority class, but also remanding for explicit consideration of the effect of the settlement on "Anglo" males). 
ments of a predominantly white union on their behalf may be the best representation they can realistically obtain before the decree is approved. ${ }^{187}$

When a court rejects the "fairness hearing" approach in a public law case, it can get into serious conceptual and practical difficulties. In United States v. City of Miami, ${ }^{188}$ the Justice Department brought a Title VII suit agamst the Miami Police Department for discrimination in hiring and promotions, naming the police union as a defendant as well. ${ }^{189}$ Shortly after the suit was filed, the Justice Department and the City submitted a detailed consent decree which included numerical "goals" for hiring and promoting minorities and women; the decree also restricted the use of civil service tests. ${ }^{190}$ The union refused to sign the proposed decree and protested that the scheme amounted to "reverse discrimination" and infringed the union's collective bargaining agreeinent. The district court held several hearings at which the union aired its objections and eventually approved a nodified decree over the continued objection of the union. ${ }^{191}$

The union appealed ${ }^{192}$ and, in a one-paragrapl per curiam decision, the Fifth Circuit en banc announced that it had been "unable to arrive at a majority consensus as to reasoning and result" in the case. ${ }^{193}$ Four separate opmions followed. Writing for five judges, Judge Rubin affirmed the approval of most of the consent decree. Judge Rubin's opinion became the mandate of the court, because a majority agreed that the union should have at least the relief afforded in that opinion. He noted that the trial judge gave the union "ample opportunity to

187. See Vulcan Soc'y v. Fire Dep't of the City of White Plains, 505 F. Supp. 955, 962 (S.D.N.Y. 1981), where the unions representing incumbent firefighters were permitted to argue that lower job qualifications for new firefighters would be against the public interest because of the risk that incompetents would be hired. The court considered these objections thoughtfully, $i d$. at 963-67, although in the end it approved the decree. Cf. United States v. City of Miami, 664 F.2d 435, 445 (5th Cir. 1981) (union has no standing to object to hiring quota because the union's nembers are already on the job). A judge who entertains objections to hiring remedies from a union must beware of the possible conflict of interest: the union might try to bargain away the interests of nonmembers in favor of the promotioual or seniority interests of its members on the job.

188. 614 F.2d 1322 (5th Cir. 1980), modified, 664 F.2d 435 (5th Cir. 1981).

189. Id.

190. Tle decree is reproduced in City of Miami, 614 F.2d at 1343-51.

191. City of Miami, 664 F.2d at 438-39.

192. In the union's initial appeal to a three judge panel, the court held that the terms of the decree were lawful and that the union's assent was not necessary. City of Miami, 614 F.2d at 1329. Judge Gee dissented, coudemning hiring and promotion quotas as improper preferential treatment, especially where the employer had not been found guilty of discrimination. Id. at 1353-55 (Gee, J., dissenting).

193. City of Miami, 664 F.2d at 436. 
muster its objections and considered its arguments fully."194 Calling the city's signature on the decree a "tacit admission of discrimination," 195 Judge Rubin concluded that the provisions of the decree, including the hiring "goals," were "im accordance with the policy of Title VII" and should be approved as between the Justice Department and the city. ${ }^{196}$ The only parts of the decree that directly affected the union, he said, were the promotion quotas and the restrictions on using civil service tests for promotions. The union, a defendant in the case, could not in Rubin's view be bound to these provisions without its consent. Judge Rubin directed that the case be remanded so that the union could contest these provisions by litigating whether the city had been guilty of discrimination. ${ }^{197}$

The case revolved around the fact that the union was named as a defendant and was never dropped as a party. ${ }^{198}$ The opinions in the case were based on the idea that a party cannot be "bound" by a judgment without its consent unless it has lost a litigated case. However, if a party is dropped it is not bound, so it cannot veto a settlement between the remaining parties. ${ }^{199}$

194. Id. at 444.

195. Id. at 442. The decree explicitly provided that it did not "constitute an adjudication or an admission by any of the defendants of any violation of law." City of Miami, 614 F.2d at 1343 .

196. City of Miami, 664 F.2d at 442.

197. Id at 447-48. Judge Gee, writing for eleven judges, would have reversed the approval of the entire consent decree as long as the union did not sign it. Id. at 451-53 (Gee, J., concurring in part and dissenting in part). As a party to the suit, said Gee, the union was entitled to a trial on the merits and an adjudcation of the facts. Id. at 452 (Gee, J., concurring in part and dissenting in part). Judge Gee suggested, however, that if the Justice Departnent and the city should conclude that binding the union to the settlement "is not after all necessary to their purposes, they may of course seek its dismissal from the case and the reentry of the decree forthwith." Id. at 453 (Gee, J., concurring in part and dissenting in part).

Judge Johnson, writing for seven judges, would have affirmed the entire consent decree because the trial judge gave the union several fairness hearings and took its objections into account before finally approving the decree. Id. at 461-63 (Johnson, J., concurring in part and dissenting in part). Judge Johnson found the settlement reasonable and concluded that it did not infringe upon the union's rights. The district judge, Johnson observed, should have dismissed the union as a party so that its consent would not be needed. Id. at 461-62 (Johnson, J., concurring in part and dissenting in part).

In a separate opimion, Judge Tjoflat concluded that the decree did not impose any relief against the union, so the court should not have entertamed the union's appeal. Id. at 453-54 (Tjoflat, J., dissenting).

198. Nineteen judges explicitly held that once the union was dismissed the decree could be approved: Judge Gee and his ten colleagues, id. at 453 , Judge Johnson and his six, id. at 462 , and Judge Tjoflat, $i d$ at 453 . The remaining five judges represented by Judge Rubin did not reject this suggestion.

199. This is the logic of the Rubin opinion: most of the decree is affirmed because it does not "affect" the union. Yet Judge Rubin's conclusion that the district court acted properly in approving nost of the decree is based in part on the fact that the district judge fully considered the union's objections to the very provisions which do not "bind" the union! See id. at 444. 
Yet the practical effect on the union's members is the same regardless of whether or not the union is a formal "party." Once a consent decree is approved, the "collateral attack" doctrine bars any lawsuit challenging the decree or seeking damages for its consequences. ${ }^{200} \mathrm{~A}$ case like United States $v$. City of Miami ends in confusion because it attempts to treat an institutional case as though it were a conventional lawsuit. In a conventional lawsuit it is the parties whose interests are primarily at stake, and the judge does not have to exercise much discretion in imposing a remedy tailored to the violation. In such a case, due process plausibly means the right to hitigate fully before being subjected to an unwelcome verdict. This right to litigate is less plausible in public law adjudication. An institutional Title VII remedy will affect the working lives of many people who are not parties to the lawsuit. If everyone affected by a public law decree had the riglt to msist on litigation, there would probably never be a consent decree and every public law case would be litigated, because there would always be at least one person dissatisfied with the choice of any remedy that might be selected.

In fact, when parties negotiate Title VII consent decrees the courts approve them in the overwhelming inajority of cases.201 This is true despite the occasional case like United States $v$. City of Miami in which a court recoils from approving a consent decree because some interested person insists that the case should be litigated. ${ }^{202}$ What varies most from case to case is the willingness of courts to permit third parties to comment and propose modifications before a decree is approved.

In cases like Kirkland and Stallworth the courts considered and approved institutional consent decrees after grantimg limited intervention to interested third parties and after holding fairness hearmgs for all concerned. This procedure, however, is not by any means universal. There are numerous Title VII suits brought by government civil rights agencies in which the courts approve consent decrees without prior notice and without hearing from anyone but the lawyers for the governinent and the employer. Minority group beneficiaries of these decrees have no opportunity to argue that the remedy is imadequate, just as whites have no chance to argue that the remedy is unfair to them. Similarly, in private class actions, although the minority class members

200. See supra notes 166-67 and accompanyimg text.

201. See supra notes $77-78$ and accompanying text.

202. The idea that imterested persons should be free to litigate is also implieit in Justice Rehnquist's dissent, joimed by Justice Brennan, in Ashley v. City of Jackson, 104 S. Ct. 255, 257 (1983) (Rehnquist, J., dissentimg), and in dictum in United States v. Jefferson County, 720 F.2d 1511, 1518 (11th Cir. 1983). 
must be notified of a settlement and given a chance to object, all too often the courts refuse to listen to nonparties. ${ }^{203}$

\section{A Systematic Approach to Procedural Fairness.}

The following procedure slould be adopted whenever the parties propose a consent decree in an institutional Title VII case:

(1) Notice of a proposed consent decree sliould be publislied so that people who are likely to be affected will have a chance to find out about it before it is approved; 204

203. When a consent decree is approved on behalf of one minority group, the possible indirect effects ou other minority groups usually get short procedural shrift in both class actions and government suits. A consent decree may diminish opportunities for other mmority groups because the employer will now give first priority to hiring or promoting the beneficiaries of the decree. The problem is particularly dramatic when a decree gives wonen retroactive seniority over blacks who are not the subjects of the lawsuit, see, e.g., EEOC v. McCall Printing Corp., 24 Fair Empl. Prac. Cas. (BNA) 437, 441 (6th Cir. 1980) (discrimination suit by wonten after blacks had negotiated an agreement granting them retroactive seniority rights), or where a decree night call for scrapping a hiring test which tends to screen out black applicants even though wonten do well on it. The existence of a consent decree does not, of course, preclude a different group from later suing the employer for discrimination. See Worley v. Western Electric Co., 28 Empl. Prac. Dec. (CCH) \{32,417 (N.D. Ga. 1981) (plaintiffs could have intervened in earlier action resulting in consent decree, but failure to do so did not defeat their right to bring independent action for sex discrimination). After the approval of a decree which gives preference to members of one group, however, another minority group will not be able to attack the preference-that would be a "collateral attack" on a consent decree. Id. at 23,818.

As a practical matter, there inay be considerable publicity about an impending consent decree, and members of various minority groups nray take the initiative and come to court with their views. In Johnson v. North Carolina State Highway Patrol, 91 F.R.D. 406 (E.D.N.C. 1980), for example, the judge refused to allow a group of Ainerican Indians to intervene before he entered a consent decree in favor of blacks and women. The Indians' objections, however, were heard and the parties modified the decree to take one of the Indians' points into account. Id. at $407 \mathrm{n} .1$.

204. Cf. 15 U.S.C. \& 16(b)-(h) (1982) (laying down procedural guidelines for antitrust consent decrees negotiated by the Justice Department). Under the Antitrust Penalties and Procedures Act, a proposed consent decree must be published in the Federal Register together with background inforination and a "competitive impact statement." 15 U.S.C. \& 16(b) (1982). A suinmary of the decree and the competitive impact statentent inust also be published in local newspapers. 15 U.S.C. § 16(c) (1982). Public comments nust be invited and published in the Federal Register. 15 U.S.C. § 16(d) (1982). The court may grant full or limited intervention to imterested persons, or may seek out other views through less formal procedures. 15 U.S.C. $\S 16(f)$ (1982). The court may approve the decree only upon a finding that it is in the public interest. 15 U.S.C. $\S 16(\mathrm{e})$ (1982).

Whatever the experience in antitrust cases, there is good reason to believe that "affirmative action impact statements" would unnecessarily bureaucratize the Title VII process; moreover, public notice in the Federal Register would reach at best a somewhat specialized class of job applicants and employees affected by Title VII consent decrees. To publicize a Title VII consent decree, newspaper notices and postings on plant bulletin boards should suffice handsoniely. See generally Branfman, Antitrust Consent Decrees-A Review and Evaluation of the First Seven Years Under the Antitrust Procedures and Penalties Act, 27 ANTITRust Bull. 303 (1982). Branfnian reports that third parties have consistently been denied full intervention, although they have been allowed to appear infornally and to object to the decree. Id. at 326-27. He concludes that the 
(2) There should be a fairness hearing about the proposed decree, open to nonparties as well as to class members. Interested third parties should be granted limited intervention as a procedural basis for their participation and as a basis for appeal; 205

(3) A union or other organization that wishes to comment on the effects of a settleunent on nonmembers of the union, such as prospective job applicants, should be permitted to do so, especially if there is no other spokesman for the interests of the nonmembers; 206

(4) The hearing should be sufficiently detailed to allow the court to appreciate the equities of the situation. In an institutional employnient discrimination case, the record should articulate the statistical evidence of discrimination. Several days may be required for an adequate airing of comments and suggestions, especially when a large employer is involved and there are numerous interested parties. The hearing, however, should not be so detailed as to permit litigation of the underlying allegations of tlie enuployer's liability under Title VII; and

(5) The court should explain wliatever action it takes, describing why a particular remedial scheıne seeıns to be justified and giving a reasoned response to objections and suggestions. ${ }^{207}$

All this should be done systematically, not erratically as at present. A statute is not a prerequisite to the adoption of these procedures; much of the substance as well as the procedure of Title VII has always been a inatter of judge-inade law. ${ }^{208}$

The procedure suggested here is reminiscent of the class action procedure for hearing objections to proposed settleinents. The difference is that fairness hearings in a class action are intended for members of the plaintiff class, whereas limited intervention is a means of giving a hearing to nonparties who stand to be affected by a consent decree. Fairness hearings are also analogous to the "notice-and-comment" procedure for ruleinaking by federal administrative agencies; that procedure allows interested parties to offer comments and suggestions-but

statute has not undermined the Justice Department's ability to negotiate consent decrees, and that the procedure has resulted in beneficial modifications in a number of decrees, id. at 352-54.

205. See First Colonial Corp. of Am. v. Baddock, 544 F.2d 1291, 1297-98 (5th Cir. 1977) (limited intervenors have standing to appeal if they are dissatisfied with the decisions of the trial court), cert. denied, 431 U.S. 904 (1977).

206. See supra note 187 and accompanying text.

207. See Metropolitan Housing Dev. v. Village of Arlington Heights, 616 F.2d 1006, 1014 (7th Cir. 1980) (when approving settlement, court must determine that settlement is fair, adequate, reasonable, and appropriate under the facts); see also Officers for Justice v. Civil Serv. Comm'n, 688 F.2d 615, 624-25 (9th Cir. 1982), cert. denied, 459 U.S. 1217 (1983).

208. See supra notes $21-30$ and accompanying text. 
not to litigate-before administrative policy decisions are adopted. ${ }^{209}$

The most obvious virtue of a fairness hearing is that when it is conducted in good faith it forces the court-and the parties as well-to consider alternatives and to articulate why a proposed decree is desirable. Because there are usually many possible remedies in a public law case and discretionary clioices must therefore be made, a liearing for third parties focuses attention on whether a particular set of remedies is as fair as possible to all concerned. A fairness liearing not only respects the autonomy of affected persons by giving thein a forum to influence the decree, it also provides a forum for the court and the parties to explam the settlement to those who may be adversely affected by it, and perhaps to reconcile them to the necessity for it.

Fairness liearings would also make trial judges' decisions about consent decrees nore accessible to appellate review. The courts of appeals routinely hold that the approval of a consent decree slould be reversed only if it is found to be an abuse of the trial judge's discretion. ${ }^{210}$ Procedural decisions, such as whether to listen to objections from third parties, are also reversible only for abuse of discretion. ${ }^{211}$ The abuse-of-discretion "standard" is something of an incantation, but in practice it means that the trial judge's approval of a settlement is usually upheld on appeal. ${ }^{212}$ There is a greater basis for intelligent ap-

209. See 5 U.S.C. $\$ 553$ (c) (1982). This provision of the Administrative Procedure Act provides for "notice-and-comment" rulemaking except when an agency is required by statute to hold trial proceedings "on the record." Id. See also $1 \mathrm{~K}$. Davls, supra note 34, at §6:1 (noting that trial-type proceedings for rulemaking have "dwindled drastically"). Professor Davis urges that there should uniformly be public notice and an opportunity to comment on pohicymaking and the finding of "legislative facts," but that trial-type proceedings are not suited to "legislative" decisionmaking. Id. at § 12:8.

210. See, e.g., Dawson v. Pastrick, 600 F.2d 70, 75 (7th Cir. 1979) (court's approval of consent decree should not be reversed in the absence of abuse of discretion, because Congress imtended settlement to be the preferred resolution of discrimination cases); Cotton v. Hinton, 559 F.2d 1326, 1331 (5th Cir. 1977); United States v. Allegheny-Ludluin Indus., 517 F.2d 826, 850 (5th Cir. 1975), cert. denied, 425 U.S. 944 (1976).

211. See Stotts v. Memphis Fire Dep't., 679 F.2d 579, 585 (6th Cir. 1982), cert. denied, 459 U.S. 969 (1982); Culbreath v. Dukakis, 630 F.2d 15, 17 (1st Cir. 1980) (trial judge has discretion to decide whether intervention is timely, and the decision is not to be reversed im absence of abuse); Stallworth v. Monsanto, 558 F.2d 257, 263 (5th Cir. 1977).

212. When a district judge refuses to approve a settlement, in whole or in part, the abuse-ofdiscretion standard is elastic enough to enable a court of appeals to reverse and to order that the decree be approved, sometimes after an analysis that resenbles a de novo review of a point of law. See, e.g., Williams v. City of New Orleans, 694 F.2d 987, $991-98$ (5th Cir.) (after ruling that de novo review by appellate court is not always appropriate, court extensively reviews evidence of reasonableness of the decree), reh'g granted, 694 F.2d 998 (5th Cir. 1982). Cf. United States v. City of Alexandria, 614 F.2d 1358, 1362 (5th Cir. 1980) (where the same court conducted an explicitly de novo review of a trial judge's refusal to approve a consent decree). In City of Alexandria, the trial judge had leard no evidence and no one had sought to intervene or to object to the decree. Id. at 1362. The court of appeals reasoned that: 
pellate review, however, when third parties have had the opportunity to put their objections on the record and the district court has responded to those objections and stated the reasons for its actions. The availability of a meaningful record increases the reahistic possibility of a "second look" by the court of appeals. ${ }^{213}$

These procedural suggestions are not, unfortunately, a panacea for the problems that surround Title VII consent decrees. Fairness hearimgs can have drawbacks for all concerned in a Title VII case. In the first place, fairness hearings increase the risk of the court finding the settlement unfair, and directing the parties either to renegotiate or to litigate. Even if the settlement is approved, the starting poimt for justifying it over any objections is usually that there is a prima facie statistical case of discrimination, which an employer may be reluctant to see articulated on the record. ${ }^{214}$ More generally, to invite objections is to risk clouding the conciliatory atmosphere which a consent decree is designed to promote. A consent decree is inherently a conpromise, and whether objections come from members of minority groups or from whites, criticisin is bound to put the plaintiff, the employer, or both on the defensive. The routine and well-publicized availability of fairness hearings in Title VII cases may actually stimulate organized opposition to many consent decrees by creating a forum in which rhetorical points can be scored at little cost to the objectors. Any or all of these considerations might diminish the willingness of some litigants to settle Title VII cases, although even with fairness hearings, settlements would still be incomparably less onerous than litigation in most large Title VII cases. $^{215}$

There remains the anomaly that an objector or limited intervenor is by definition precluded from litigating the underlying merits of the case. It is a partial answer to say that the remedy in an institutional

\footnotetext{
We do not carry the mistaken notion that heightened review of district court refusals to enter consent decrees will resolve the almost intractable probleuns in this area. But we do not believe that individual federal judges should have almost unchallengeable power to slow or halt the progress of well-intentioned efforts to eradicate the effects of past discrimination and prevent future discrimination.

Id.

213. Such appellate accountability would not prevent the federal courts from continuing to view consent decrees as presumptively valid. See Officers for Justice v. Civil Service Comm'n, 688 F.2d 615, 626 (9th Cir. 1982) (announcing that approval of the consent decree would only be reversed for "clear abuse of discretion"), cert. denied, 459 U.S. 1217 (1983). In its opinion, however, the Ninth Circuit treated the various objections to the decree seriously enough to analyze them in depth and at some length. See id. at 626-36.

214. One reason for articulating the prima facie case is that it might help reconcile the affected whites to the need for a Title VII remedy.

215. See United States v. Allegheny-Ludlum Indus., 517 F.2d 826, 85 I n.28 (5th Cir. 1975) (speculating that full litigation of the case might take 28 years), cert. denied, 425 U.S. 944 (1976).
} 
case is prospective and not strictly based on the violation-that public law is about making policy for the future and that the details of the underlymg violation are irrelevant. This is true, but only up to a point. ${ }^{216}$ The anomaly is explained but not resolved by saying that institutional cooperation is essential for effective reform under a law like Title VII; consent decrees are therefore desirable, third parties should not be given a veto, and it is better to give such third parties a hearing on the choice of a remedy than to exclude them froin the process entirely.

There is even some ambiguity about what third parties can gain by participatimg in fairness hearmgs. They can certainly protest the occasional settlement that is clearly illegal-a decree endorsing discrimination, for imstance, or one calling for a permanent one-hundred-percent quota for minorities. Within broad limits, however, institutional remedies are discretionary; any number of possible remedies would be legal.217 There is some cathartic value in loolding fairness hearings before putting the court's authority behind any major institutional change; an open forum for those affected is partly a ritual of "hearmg all sides." Still, psychodrama is not an end in itself, and fairness hearings do not abolish the remedial discretion that goes into a consent decree.

What third parties can do through fairness hearings and limited intervention is to influence informally the exercise of that discretion. In numerous cases, the cominents and objections of third parties have in fact evoked modifications of consent decrees. ${ }^{218}$ Participants in fairness hearings are free to suggest alternatives. Their success will depend

216. Cf. generally E. WAUGH, SCOOP passim (1937) (the hilarious novel in which a newspaper tycoon's underlings reply "Definitely, Lord Copper" when they mean "yes," and "Up to a point" when they inean "no.").

217. Professor William Fletcher has suggested that by histening to interested nonparties, the courts may be tempted to "balance" away the remedial rights of the parties in favor of the nonlegal interests of the nonparties. Fletcher, supra note 100, at 658-59. This might indeed be a danger if the plaintiff had a legal "right" to soine particular remedy. The nature of institutional litigation, however, is that there is no one "correct" remedy. In each case it is a natter of discretion and choosing a good policy. (Fletcher is generally troubled about the legitimacy of institutional adjudication precisely because it entails so much open-ended discretion. Id. passim.).

218. See, e.g., Dawson v. Pastrick, 600 F.2d 70, 73-74 (7th Cir. 1979) (trial court withdrew its approval for a partial consent decree establishing racial hiring quotas, after intervenor-union objected); Vulcan Soc'y v. Fire Dep't, 505 F. Supp. 955, 960 (S.D.N.Y. 1981) (consent decree as originally proposed would have abolished requirenent of high school diplona for firefighters; requirement reinstated in revised decree after objectious by union intervenor); see also United States v. City of Miami, 664 F.2d 435, 438-39 (5th Cir. 1981) (parties modified the peusion provisions of their settlement after union objections at a hearing on entry of the decree in the district court); EEOC v. Wood Wire \& Metal Lathers' Union Local 11, 23 Fed. R. Serv. 2d (Callaghan) 567, 568 (4th Cir. 1977) (case remanded for possible nodification of consent decree in response to intervenor's objections); Johnson v. North Carolina State Highway Patrol, 91 F.R.D. 406, 407 n.1 
on their persuasiveness. Procedural fairness means the opportunity to be persuasive.

\section{CONCLUSION}

Title VII adjudication is an example of how courts have become a forum for institutional change in American society. Although the forum is judicial, public law cases are often not litigated; instead, the parties negotiate broad pohicy prescriptions which the courts approve in the form of consent decrees. Even in a fully litigated public law case, the existing rules of procedure do not oblige the courts to hear from all the innumerable people with an interest in the outcome; but at least the decision affecting those interests is that of the court, not the parties, and it is based on a factual record developed through the adversary process. With a consent decree, on the other hand, far-reaching institutional reforms can be negotiated by parties who do not represent all the interests that will be affected, and the courts often ratify these reforms independently of the adversary process.

The federal courts have willingly-_even eagerly_-embraced public law consent decrees. They have had good reason for doimg so. Broad public law statutes like Title VII make the courts responsible for defin$\mathrm{mg}$ and enforcing reforms in a large number of public and private mstitutions. Compulsory litigation of every case would be prohibitively expensive, and would undermine the cooperative and noncoercive atmosphere in which complex reforms are best planned and carried out.

In welcoming consent decrees, however, the courts have failed to develop any consistent procedure for hearing from interested nonparties. The reasons for this failure are not difficult to divime. Consent decrees are convenient and perhaps indispensable for the effective enforcement of the statute. It would be self-defeating for the courts to give third parties the right to insist on litigation and thus to veto consent decrees. Short of the right to litigate, any hearmg for third parties smacks more of legislative or administrative activity than of judicial procedure. Many courts have been reluctant to face the imphications of how the legislative and adjudicative styles of decisionmaking converge in public law cases. Hence the fiction that the parties' interests are the only ones at stake and the refusal im many cases to histen to nonparties.

This article recommends fairness hearmgs, open to all concerned, before the approval of Title VII consent decrees. To approve a consent decree without such hearings is to diminish the autonomy of those de-

(E.D.N.C. 1980) (parties amended the hiring provisions of their decree to take account of objections of third-party American Indians). 
nied their "day in court." Also, without fairness hearings, the court has less information to rely on to inake a responsible decision about the decree.

Greater procedural fairness in consent decree cases will not, of course, resolve the substantive dilemmas that surround "affirmative action." "Affirmative action" will continue to raise unusually difficult questions of policy, because the conflicting calls for colorblindness and for racial reconstruction are each so resonant. "Affirmative action" is a hve political issue precisely because there is no clear right answer; ,eacl side in the debate can invoke public values implicit in the Constitution and in the civil rights statutes. ${ }^{219}$ Greater procedural openness and inore judicial oversight might, however, lead to a better focused view of whiclr mimority groups sliould receive preferences, for what kinds of jobs, and with what objectives in mind. ${ }^{220}$ It miglit also help reconcile whites and other objectors to the propriety of the reniedies the courts approve.

219. One plausible view of "equal opportunity" is that people should be treated as individuals without regard to their race, and that the time for the law to enforce this principle is now. On this view, quotas and other racial preferences are inherently unfair: unfair to whites who are penalized because of their race, unfair to society which continues to be distorted by allocations on the basis of race, and unfair to minorities who are stigmatized as requiring special preferences. For a sample of scholarly writings that are generally critical of "affirmative action," see A. BICKEL, THE MORAlity of CONSENT 133 (1975); N. Glazer, AfFirmative Discrimination (1975); Kurland, Ruminations on the Quality of Equality, 1979 B.Y.U. L. REv. I; Posner, The Bakke Case and the Future of Affirmative Action, 67 CALIF. L. REv. 171 (1979); Scalia, The Disease as Cure, 1979 WASH. U.L.Q. 147; Van Alstyne, Rites of Passage: Race, The Supreme Court, and the Constitution, 46 U. CHr. L. REV. 775 (1979).

The opposite view also draws on values implicit in the idea of "equal opportunity." This view emphasizes America's long and bitter history of discrimination, and urges that since minorities were victimized as groups they now require compensatory preference on a group basis. Fairness, on this view, requires group preferences as the ouly effective way to end invidious discrimination and to remedy the continuing economic and hunian effects of past discrimination. See Justice Marshall's eloquent opimion in Regents of the Univ. of Cal. v. Bakke, 438 U.S. 265, 387 (1978) (concurring in part and dissenting in part). For a sample of scholarly writings that generally support "affirmative action," see Ely, The Constitutionality of Reverse Racial Discrimination, 41 U. CHI. L. REv. 723 (1974); Greenawalt, The Unresolved Problems of Reverse Discrimination, 67 CALIF. L. REv. 87 (1979); Griswold, The Bakke Problem, 1979 WASH. U.L.Q. 55; Karst \& Horowitz, Affirmative Action and Equal Protection, 60 VA. L. Rev. 955 (1974). See generally Equality and Preferential Treatment (M. Cohen, T. Scanlon \& T. Nagel eds. 1977); $R$. Fullinwinder, The Reverse Discrimination Controversy: A Moral and Legal AnalySIS (1980).

220. Cf. C. Jencks, Affirmative Action, New York Review of Books, Mar. 3, 1983, at 33 (pt. 1) and Mar. 17, 1983, at 12 (pt. 2). Jencks explores the human and social costs of "affirmative action," as well as the argunents for it, and suggests that minority quotas should not be higher than are necessary to discourage actual invidious discrimination against minorities. See also Jencks, Sowell, Glaberman, \& Schwarzschild, Ethnic America: An Exchange, New York Review of Books, June 16, 1983, at 47; Scanlan, Employment Quotas for Women?, 73 THE PUB. INTEREST 106, 108-10 (1983) (arguing that quotas are so problematic that they should be reserved for blacks, whose history and present situation in this country are unique). 
Whatever the outcome in these cases, it will be impossible to please everyone. Consent decrees will at least promote honest public debate instead of frustrating it so long as the courts are prepared to justify the settlements they approve. This requires facing the people affected and articulating the public values that underlie each decision.

Fairness hearings in consent decree cases are one step towards the recognition that courts are part of the government and that public law remedies are governmental policy decisions. Governments, like individuals, inust make decisions about their future without conclusive assurances that their decisions are correct. Fairness hearings are an opportunity for dialogue about institutional reforn. Dialogue preserves the intellectual integrity and the fidelity to public values which, after all, are the bases of the courts' authority to decide public questions. 